This Accepted Author Manuscript is copyrighted and published by Elsevier. It is posted here by agreement between Elsevier and University of Brasilia. Changes resulting from the publishing process - such as editing, corrections, structural formatting, and other quality control mechanisms - may not be reflected in this version of the text. The definitive version of the text was subsequently published in [ Tissue \& Cell, Volume 39, Issue 1, February 2007 Pages 59-78, doi:10.1016/j.tice.2006.12.001].You may download, copy and otherwise use the AAM for noncommercial purposes provided that your license is limited by the following restrictions:

(1) You may use this AAM for non-commercial purposes only under the terms of the CC-BY-NCND license.

(2) The integrity of the work and identification of the author, copyright owner, and publisher must be preserved in any copy.

(3) You must attribute this AAM in the following format: [agreed attribution language, including link to CC BY-NC-ND license + Digital Object Identifier link to the published journal article on Elsevier's ScienceDirect ${ }^{\circledR}$ platform].

Este Manuscrito do Autor Aceito para Publicação (AAM) é protegido por direitos autorais e publicado pela Elsevier. Ele esta disponível neste Repositório, por acordo entre a Elsevier e a Universidade de Brasília. As alterações decorrentes do processo de publicação - como a edição, correção, formatação estrutural, e outros mecanismos de controle de qualidade - não estão refletidas nesta versão do texto. A versão definitiva do texto foi posteriormente publicado em [Tissue \& Cell, Volume 39, Número 1, Fevereiro 2007, Páginas Pages 59-78

doi:10.1016/j.tice.2006.12.001]. Você pode baixar, copiar e utilizar de outra forma o AAM para fins não comerciais, desde que sua licença seja limitada pelas seguintes restrições:

(1) Você pode usar este AAM para fins não comerciais apenas sob os termos da licença CC- BYNC-ND.

(2) A integridade do trabalho e identificação do autor, detentor dos direitos autorais e editor deve ser preservado em qualquer cópia.

(3) Tem de atribuir este AAM no seguinte formato: [acordo na linguagem atribuída, incluindo o link para CC BY-NC-ND licença Digital + DOI do artigo publicado na revista Elsevier ScienceDirect ${ }^{\circledR}$ da plataforma]. 


\title{
Comparative study of sperm ultrastructure of five species of teiid lizards (Teiidae, Squamata), and Cercosaura ocellata (Gymnophthalmidae, Squamata)
}

\author{
G.R. Colli \\ R.D. Teixeira \\ D.M. Scheltinga \\ D.O. Mesquita \\ H.C. Wiederhecker \\ S.N. Báo
}

\section{Abstract}

Sperm ultrastructure of five teiid lizards (Callopistes flavipunctatus, Crocodilurus amazonicus, Dicrodon guttulatum, Dracaena guianensis, and Teius oculatus), and the gymnophthalmid Cercosaura ocellata is described for the first time. Comparisons of sperm ultrastructure among these species and with those of previously examined teiids and gymnophthalmids revealed that the two groups of Teiioidea (Gymnophthalmidae and Teiidae), and the two subfamilies of Teiidae (Teiinae and Tupinambinae) could be distinguished on the basis of sperm ultrastructure data. Significant differences in sperm dimensions between Cnemidophorus and Aspidoscelis support the recent splitting of these two lineages into different genera. Our results revealed high levels of inter-generic variability in sperm ultrastructure within Teiidae, which produces a data set useful in analyzing relationships between genera and families. In phylogenetic analyses, however, sampling multiple species within teiid genera is essential and recording sperm measurements may profitably complement qualitative ultrastructural characters, maximizing the information content of these structures.

Keywords: Sperm ultrastructure; Lizard spermatozoa; Squamata; Teiidae; Gymnophthalmidae

\section{Introduction}

The lizard family Teiidae is composed by 10 genera grouped in two subfamilies, Teiinae and Tupinambinae (Presch, 1974). Teiinae comprises Ameiva, Aspidoscelis, Cnemidophorus, Dicrodon, Kentropyx, and Teius, whereas Tupinambinae comprises Callopistes, Crocodilurus, Dracaena, and Tupinambis. Aspidoscelis was recently resurrected by Reeder et al. (2002), based on molecular, allozymic, and morphological data, comprising the whiptails from Central and North America (deppii, sexlineata, and tigris groups). Despite several attempts to clarify the relationships among teiid genera using morphological data ( Vanzolini and Valencia, 1965, Gorman, 1970, Presch, 1974, Rieppel, 1980, Veronese and Krause, 1997 and Moro and Abdala, 2000), this issue is still largely unresolved.

The ultrastructure of sperm has been used as an alternate source of characters for phylogenetic analyses of several reptilian taxa. Sperm data contain significant phylogenetic information and are especially useful when other character sets are not enlightening 
(Jamieson, 1995a, Jamieson, 1995b, Oliver et al., 1996, Teixeira et al., 1999a and Teixeira et al., 1999b). Analysis of the degree of variability in sperm ultrastructure characters across taxonomic categories can reveal the most profitable taxonomic level at which phylogenetic analyses should be carried out (Giugliano et al., 2002). Previous studies have described the sperm ultrastructure of the teiids Aspidoscelis sexlineata ( Newton and Trauth, 1992), Ameiva ameiva ( Giugliano et al., 2002), Tupinambis duseni, T. merianae, T. quadrilineatus, and T. teguixin ( Tavares-Bastos et al., 2002), and Aspidoscelis gularis gularis, Cnemidophorus ocellifer, and Kentropyx altamazonica ( Teixeira et al., 2002). These studies revealed high levels of variability among teiid genera. We here describe the sperm ultrastructure of the teiids Callopistes flavipunctatus, Crocodilurus amazonicus, Dicrodon guttulatum, Dracaena guianensis, and Teius oculatus, and the gymnophthalmid Cercosaura ocellata. We then make comparisons among these species and with the previously examined species of Tupinambinae, Tupinambis teguixin ( Tavares-Bastos et al., 2002), and Teiinae, A. ameiva ( Giugliano et al., 2002).

\section{Materials and methods}

\subsection{Spermatozoa ultrastructure}

Mature spermatozoa were obtained from adult specimens of D. guttulatum (Museo de Historia Natural de San Marcos, MHNSM uncatalogued) and C. flavipunctatus (MHNSM uncatalogued) collected by RDT and GRC in Chiclayo, Peru; C. amazonicus (Coleção Herpetológica da Universidade de Brasília, CHUNB 15192) and D. guianensis (CHUNB 15197, 15198, 15199), collected in Amapá, Amapá state, Brazil; T. oculatus (CHUNB 21861, 21862) collected in Porto Alegre, Rio Grande do Sul state, Brazil; and C. ocellata (CHUNB 18272) collected in Pimenta Bueno, Rondônia, Brazil.

Lizards were humanely sacrificed by an injection of Tiopental ${ }^{\circledast}$. Epididymides were removed and placed on a Petri dish with phosphate buffered saline (PBS), $\mathrm{pH} 7.2$, and cut into small pieces. Epididymal tissues were then fixed in a solution containing $2 \%$ glutaraldehyde, $2 \%$ paraformaldehyde, and $3 \%$ sucrose in $0.1 \mathrm{M}$ sodium cacodylate buffer, $\mathrm{pH} 7.2$, at $4{ }^{\circ} \mathrm{C}$ overnight. Tissue samples were then rinsed in $0.1 \mathrm{M}$ sodium cacodylate buffer, $\mathrm{pH}$ 7.2; postfixed for $80 \mathrm{~min}$ in similarly buffered 1\% osmium tetroxide; rinsed in buffer; dehydrated through series of ascending acetone series (30-100\%) and embedded in Spurr's epoxy resin. Ultrathin sections were stained for $30 \mathrm{~s}$ in Reynold's lead citrate, rinsed in distilled water, then 
in 3\% aqueous uranyl acetate for $4 \mathrm{~min}$, rinsed in distilled water, and stained for a further 2 min in lead citrate before final rinsing. Electron micrographs were taken on a JEOL $100 \mathrm{C}$ transmission electron microscope at $80 \mathrm{kV}$.

Light microscopic observations and photographs of glutaraldehyde-paraformaldehyde fixed smears of C. flavipunctatus, C. amazonicus, D. guttulatum, D. guianensis, T. oculatus, and C. ocellata spermatozoa were made under Nomarski interference contrast using a Zeiss Axiophot microscope. To provide comparisons with the remaining teiid genera, we used published data on A. ameiva ( Giugliano et al., 2002), T. teguixin ( Tavares-Bastos et al., 2002), and A. gularis, C. ocellifer, and K. altamazonica ( Teixeira et al., 2002).

\subsection{Spermatozoa measurements}

The following dimensions were measured from micrographs obtained for each species of the present study, and from previously published accounts on T. teguixin ( Tavares-Bastos et al., 2002), A. ameiva ( Giugliano et al., 2002), and A. gularis, C. ocellifer, and K. altamazonica ( Teixeira et al., 2002): head length (HL), tail length (TL), entire sperm length (ESL), midpiece length (MPL), acrosome length (AL), nucleus base width (NBW), nuclear rostrum length (NRL), distal centriole length (DCL), epinuclear lucent zone length (ETL) and width (ETW), nuclear shoulder width (NSW), ratio of anterior principal piece diameter to midpiece diameter (RD), and ratio of anterior principal piece diameter to fibrous sheath diameter (RC). As the assumption of normality was not met, original variables were ranked prior to analyses ( Zar, 1998). To test the null hypothesis of no difference in sperm dimensions among the five species, a separate analysis of variance (ANOVA) was performed for each variable. This univariate approach was adopted because complete sets of measurements could not be obtained from individual sperm cells. To avoid the inflation of Type I error, the Bonferroni procedure was adopted by dividing the significance level of $5 \%$ by the number of tests (13), resulting in a significance level of $0.3 \%$ ( Zar, 1998). The Tukey test was used to test for pairwise differences among means. Statistical analyses were conducted with SAS v. 8.0 and Systat v. 9.0 for Windows. Throughout the text, means are given \pm 1 standard deviation.

\section{Results}

Spermatozoa of C. flavipunctatus, C. amazonicus, D. guttulatum, D. guianensis, T. oculatus, and C. ocellata are filiform, consisting of a head region containing acrosomal structures and the nucleus, a midpiece, and a tail region subdivided into principal piece and 
endpiece ( Fig. 2 and Fig. 8). The spermatozoa of all six species are sufficiently similar to be described together with any differences noted. The spermatozoa of D. guttulatum and T. oculatus are diagrammatically represented in Fig. 1. Variable features among the six species studied are provided in Table 1.

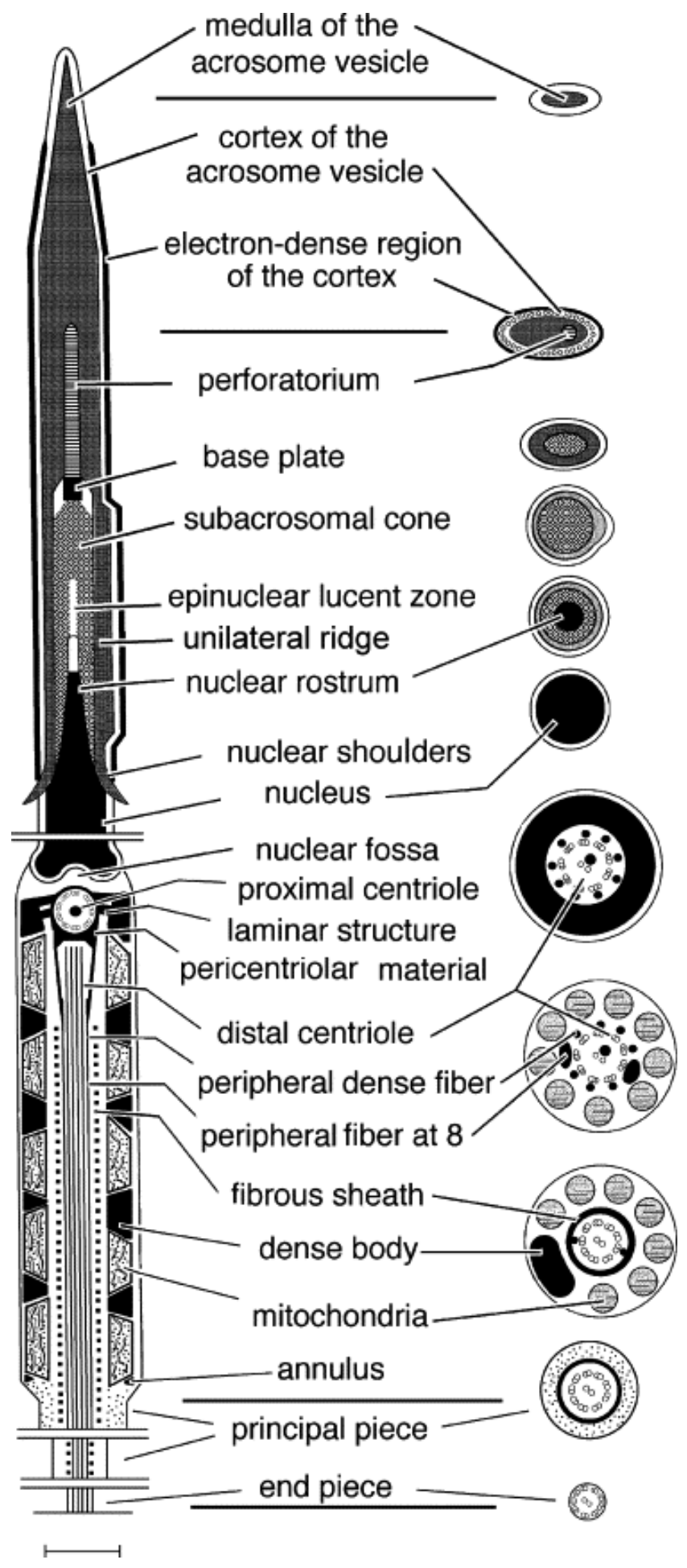

Fig. 1. D. guttulatum and T. oculatus. Diagram of the spermatozoon, with corresponding transverse sections. Scale bar $0.5 \mu \mathrm{m}$. 
Table 1

Distribution of sperm ultrastructure features among teiid genera and Cercosaura (Gymnophthalmidae)

\begin{tabular}{|c|c|c|c|c|c|c|c|c|}
\hline Species & UR & $\mathrm{AV}$ & BP & BP shape & BP in SC material & LS & LS & $\mathrm{CD}$ in $\mathrm{PC}$ \\
\hline Ameiva $^{\mathrm{a}}$ & Present & Tubular & Present & Stopper-like & Embedded & Well developed & Bilateral & Present \\
\hline Aspidoscelis $^{\mathrm{a}}$ & Present & Tubular & Present & Stopper-like & Embedded & Well developed & Bilateral & Present \\
\hline Cnemidophorus $^{\mathrm{a}}$ & Present & Tubular & Present & Stopper-like & Embedded & Well developed & Bilateral & Present \\
\hline Dicrodon $^{\mathrm{a}}$ & Present & Tubular & Present & Stopper-like & Not embedded & Well developed & Bilateral & Present \\
\hline Kentropyx ${ }^{2}$ & Present & Tubular & Absent & - & Embedded & Well developed & Bilateral & Present \\
\hline Teius" & Present & Tubular & Present & Stopper-like & Not embedded & Well developed & Bilateral & Present \\
\hline Callopistes $^{\mathrm{b}}$ & Present & Tubular & Present & Stopper-like & Embedded & Well developed & Bilateral & Present \\
\hline Crocodilurus $^{\mathrm{b}}$ & Present & Tubular & Present & Stopper-like & Embedded & Well developed & Bilateral & Absent \\
\hline Dracaena $^{\mathrm{b}}$ & Present & Tubular & Present & Stopper-like & Embedded & Well developed & Bilateral & Absent \\
\hline Tupinambis $^{\mathrm{b}}$ & Present & Tubular & Present & Knob-like & Embedded & Well developed & Bilateral & Present \\
\hline Cercosaura ${ }^{c}$ & Absent & Not tubular & Absent & - & Embedded & Poorly developed & Unilateral & Absent \\
\hline Species & Fibers & Number & Mi shape 1 & Mi shape 2 & RS & Dense bodies & Mi between & Beginning \\
\hline Ameiva $a^{a}$ & Grossly enlarged & 5 sets & Columnar & Trapezoidal & Present & Fused & Absent & $\mathrm{Mi} 2$ \\
\hline Aspidoscelis $^{\mathrm{a}}$ & Not grossly enlarged & 5 sets & Columnar & Trapezoidal & Present & Fused & Absent & Mi2 \\
\hline Cnemidophorus $^{\mathrm{a}}$ & Not grossly enlarged & 5 sets & Columnar & Trapezoidal & Present & Fused & Absent & Mi2 \\
\hline Dicrodon $^{\mathrm{a}}$ & Grossly enlarged & 5 sets & Columnar & Trapezoidal & Present & Fused & Absent & Mi2 \\
\hline Kentropyx $x^{2}$ & Grossly enlarged & 5 sets & Slightly curved & Round ended & Present & Fused & Absent & Mil \\
\hline Teius $^{\mathrm{T}}$ & Grossly enlarged & 5 sets & Columnar & Trapezoidal & Present & Fused & Absent & $\mathrm{Mi} 2$ \\
\hline Callopistes $^{\mathrm{b}}$ & Grossly enlarged & 3 sets & Columnar & Trapezoidal & Present & Not fused & Absent & $\mathrm{Mi} 2$ \\
\hline Crocodilurus $^{\mathrm{b}}$ & Grossly enlarged & 6 sets & Columnar & Round ended & Present & Not fused & Absent & Mi3 \\
\hline Dracaena $^{\mathrm{b}}$ & Grossly enlarged & 6 sets & Columnar & Round ended & Present & Not fused & Absent & $\mathrm{Mi} 3$ \\
\hline Tupinambis ${ }^{\mathrm{b}}$ & Not grossly enlarged & 6 sets & Columnar & Trapezoidal & Present & Not fused & Absent & $\mathrm{Mi} 3$ \\
\hline Cercosaura $^{c}$ & Grossly enlarged & 5 sets & Columnar & Trapezoidal & Absent & - & Present & $\mathrm{Mi3}$ \\
\hline
\end{tabular}

Note: UR, unilateral ridge; $\mathrm{AV}$, acrosome vesicle; $\mathrm{BP}$, base plate; $\mathrm{BP}$ in SC material, base plate in relation to subacrosomal cone material; $L S$, laminar structure; $C D$ in $P C$, central density in proximal centriole; Fibers, peripheral fibers at doublets 3 and 8; Number, sets of mitochondrial tiers and ring structures; $\mathrm{Mi}$ shape 1, mitochondria shape; Mi shape 2, mitochondria shape; RS, ring structures; Mi between, mitochondria separating isolated dense rings, not ring structures; Beginning, mitochondrial tier reached by fibrous sheath in midpiece.

a Teiinae.

b Tupinambinae.

c Gymnophthalmidae.

\subsection{Acrosome complex}

Apically, the acrosome complex appears sharply attenuated in one plane (Fig. 2, Fig. 6, Fig. 7 and Fig. 8) and flattened and spatulate in the other plane (Fig. 2 and Fig. 7). It is circular at its base and becomes increasingly depressed in transverse section near the anterior tip (Fig. 2, Fig. 6, Fig. 7 and Fig. 8). The acrosome consists of two caps: an external cap, the acrosome vesicle, and an internal cap, the subacrosomal cone (Fig. 2, Fig. 6, Fig. 7 and Fig. 8). With the exception of Cercosaura, the acrosome vesicle forms a protuberance, appearing as a unilateral ridge at the acrosome surface ( Fig. 2, Fig. 6, Fig. 7 and Fig. 8). The acrosome vesicle caps the subacrosomal cone, and anteriorly can be divided into a narrow outer cortex surrounding a wide, central medulla ( Fig. 2, Fig. 6, Fig. 7 and Fig. 8). In transverse sections of all teiids, but not in Cercosaura, ( Fig. 2, Fig. 6, Fig. 7 and Fig. 8), the cortex exhibits a tubular organization within its anterior portion. In teiids and Cercosaura, the medulla appears as a moderately electron-dense structure, filling the interior of the acrosome vesicle. 

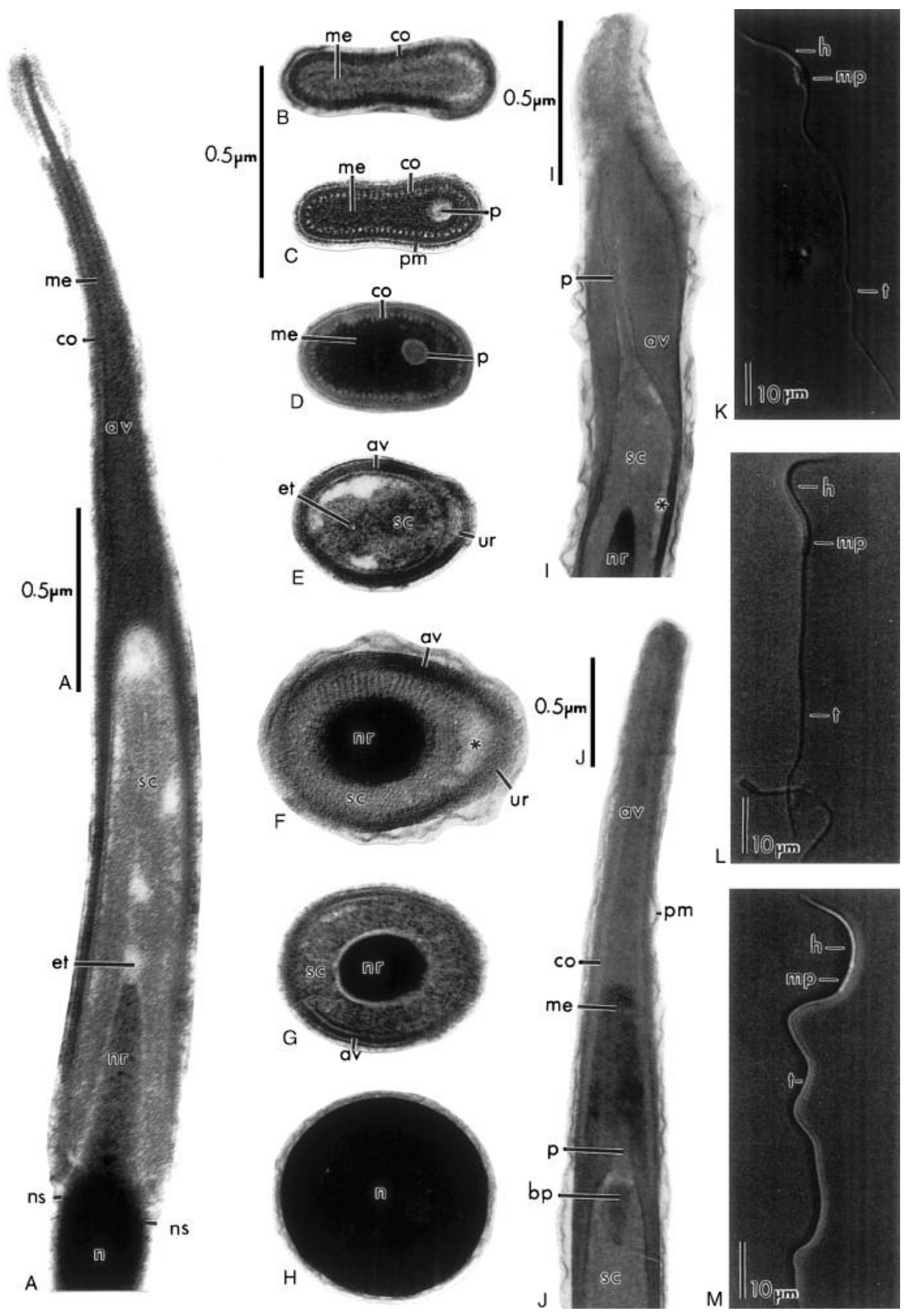

Fig. 2. Spermatozoa of $C$. flavipunctatus $(A, B, I-K)$, C. amazonicus (C, D, F-H, L), and D. guianensis $(E, M)$. (A-J) Transmission electron micrographs through sperm head (acrosome complex and nucleus). (A) Longitudinal section (LS) through the acrosome complex showing the acrosome vesicle with cortex and medulla, the subacrosomal cone, and the nuclear rostrum. Note the epinuclear lucent zone at the nucleus tip. (B-G) A series of transverse sections (TSs) through the sperm head as indicated. Note that anteriorly, in (B-D), the acrosome appears depressed, while posteriorly, in (E) and (F) it possess a 
unilaterally ridge; (G), the acrosome more circular. (H) TS through the nucleus. (I) LS of the acrosome complex, showing the flattened apical region. Note the perforatorium and the electron-lucent space between subacrosomal cone and the acrosome vesicle $\left({ }^{*}\right)$. $(\mathrm{J})$ LS of the acrosome complex showing the stopper-like perforatorial base plate embedded in the subacrosomal material. (K-M) Light micrographs showing whole spermatozoon of C. flavipunctatus (K), C. amazonicus (L), and D. guianensis (M). (B-H) to same scale as indicated. av, acrosome vesicle; bp, perforatorial base plate; co, cortex; et, epinuclear lucent zone; $\mathrm{h}$, head; me, medulla; $\mathrm{mp}$, midpiece; $\mathrm{n}$, nucleus; $\mathrm{nr}$, nuclear rostrum; $\mathrm{ns}$, nuclear shoulder; p, perforatorium; pm, plasma membrane; sc, subacrosomal cone; t: tail; ur, unilateral ridge.

A slender rod, the perforatorium, extends from the anterior region of the subacrosomal cone into the medullar portion of the acrosome vesicle (Fig. 2, Fig. 7 and Fig. 8). The perforatorium has a rounded apical tip and, when viewed in transverse section (anteriorly), occurs outside the central one third of the flattened acrosome (Fig. 2, Fig. 6, Fig. 7 and Fig. 8). Posteriorly, a stopper-like base plate is present at the perforatorium base, except in Cercosaura, where a perforatorial base plate is absent. However, a densification is observed within the apex of the subacrosomal material ( Fig. 8A). In C. flavipunctatus, C. amazonicus, and D. guianensis the base plate is embedded within the anterior extremity of the subacrosomal cone ( Fig. 2J), whereas in T. oculatus and D. guttulatum the base plate is not embedded in subacrosomal material ( Fig. 6 and Fig. 7).

In all species, the underlying subacrosomal cone surrounds the tapered anterior end of the nucleus and exhibits a paracrystalline structure (Fig. 2, Fig. 6, Fig. 7 and Fig. 8). Within the anterior region of the subacrosomal cone, immediately anterior to the nuclear tip, an epinuclear electron-lucent zone is present (Fig. 2, Fig. 6, Fig. 7 and Fig. 8).

\subsection{Nucleus}

The elongated nucleus consists of highly condensed, electron-dense chromatin. In transverse section, the nucleus is circular throughout (Fig. 2, Fig. 6, Fig. 7 and Fig. 8). The nucleus tapers anteriorly to form a slender cone, the nuclear rostrum, within the acrosome complex. The nuclear rostrum is distinguished from the main part of the cylindrical nucleus by abrupt and rounded nuclear shoulders (Fig. 2, Fig. 6, Fig. 7 and Fig. 8). Basally, the nucleus ends with a shallow concave depression, the nuclear fossa, which houses the anterior half of the proximal centriole and dense pericentriolar material (Fig. 3, Fig. 4, Fig. 5, Fig. 6, Fig. 7 and Fig. 8). 


\subsection{Neck region}

The neck region occurs at the junction between nucleus and midpiece. It includes the proximal and distal centrioles, the first ring of dense bodies, and mitochondria (Fig. 3, Fig. 4, Fig. 5, Fig. 6, Fig. 7 and Fig. 8). The proximal centriole is composed of nine short microtubule triplets and lies anterior to the distal centriole (Fig. 3, Fig. 4, Fig. 5, Fig. 6, Fig. 7 and Fig. 8). In C. flavipunctatus, D. guttulatum, and T. oculatus, an electron-dense body is present within the center of the proximal centriole ( Fig. 3, Fig. 6, Fig. 7 and Fig. 8). This electron-dense material is similar in density and composition to that of the dense bodies of the midpiece. The distal centriole consists of nine triplets of microtubules and forms the basal body of the axoneme. Nine peripheral fibers that partially cover each of the triplets are present. The distal centriole lies in the long axis of the spermatozoon, occupying a small fraction of the midpiece, and does not project into the fibrous sheath ( Fig. 3, Fig. 4, Fig. 5, Fig. 6, Fig. 7 and Fig. 8). Compact dense material, the pericentriolar material, surrounds the proximal centriole and in longitudinal section of the sperm is seen to project bilaterally, from both sides of the anterior limit of the proximal centriole, as a laminar structure ( Fig. 3, Fig. 4, Fig. 5, Fig. 6, Fig. 7 and Fig. 8). This material extends posteriorly around the distal centriole, forming a base for the nine peripheral dense fibers ( Fig. 3, Fig. 4, Fig. 5, Fig. 6, Fig. 7 and Fig. 8). In Cercosaura, the laminar structure is poorly developed and projects unilaterally ( Fig. 8B). 

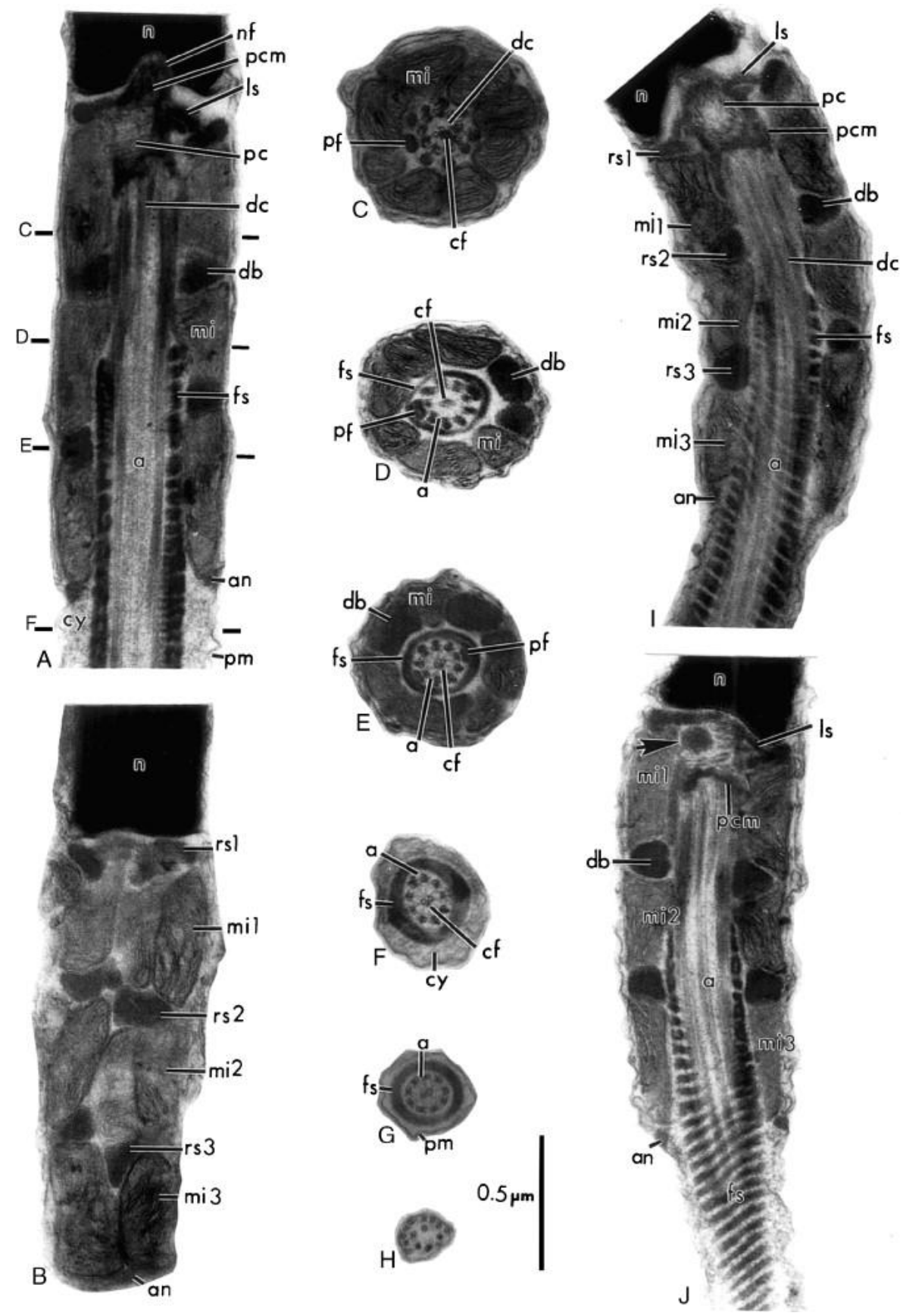

Fig. 3. Spermatozoa of C. flavipunctatus. (A-J) Transmission electron micrographs of the tail (midpiece, principal piece and endpiece). (A) Longitudinal section (LS) through the midpiece showing the distal centriole, axoneme, fibrous sheath, mitochondrial dense bodies and annulus. (B) LS through the midpiece showing the mitochondrial and dense body arrangement. (C-H) A series of transverse sections (TSs) through the sperm tail as indicated; (C) distal centriole showing the pair of central microtubules and the dense material within it; (D) the beginning of the axoneme showing the grossly enlarged fibers 3 and $8 ;(E)$ the axoneme showing that the peripheral fibers at 3 and 8 are thicker than the others and are detached from their doublets; (F) the anterior region of the principal piece; (G) the posterior end of the principal piece; $(\mathrm{H})$ the endpiece with disarranged microtubules pattern. (I) LS of the midpiece showing bilateral laminar structure. (J) LS of the midpiece showing central density within the proximal centriole. (A-J) to same scale as indicated. a, axoneme; an, annulus; cf, central fiber; cy, cytoplasm; db, dense bodies; dc, distal centriole; fs, fibrous sheath; Is, laminar structure; mi, mitochondrial tier; $\mathrm{n}$, nucleus; $\mathrm{nf}$, nuclear fossa; pc, proximal centriole; pf, peripheral fibers; pm, plasma membrane; pcm, pericentriolar material; rs, dense body ring structure. 

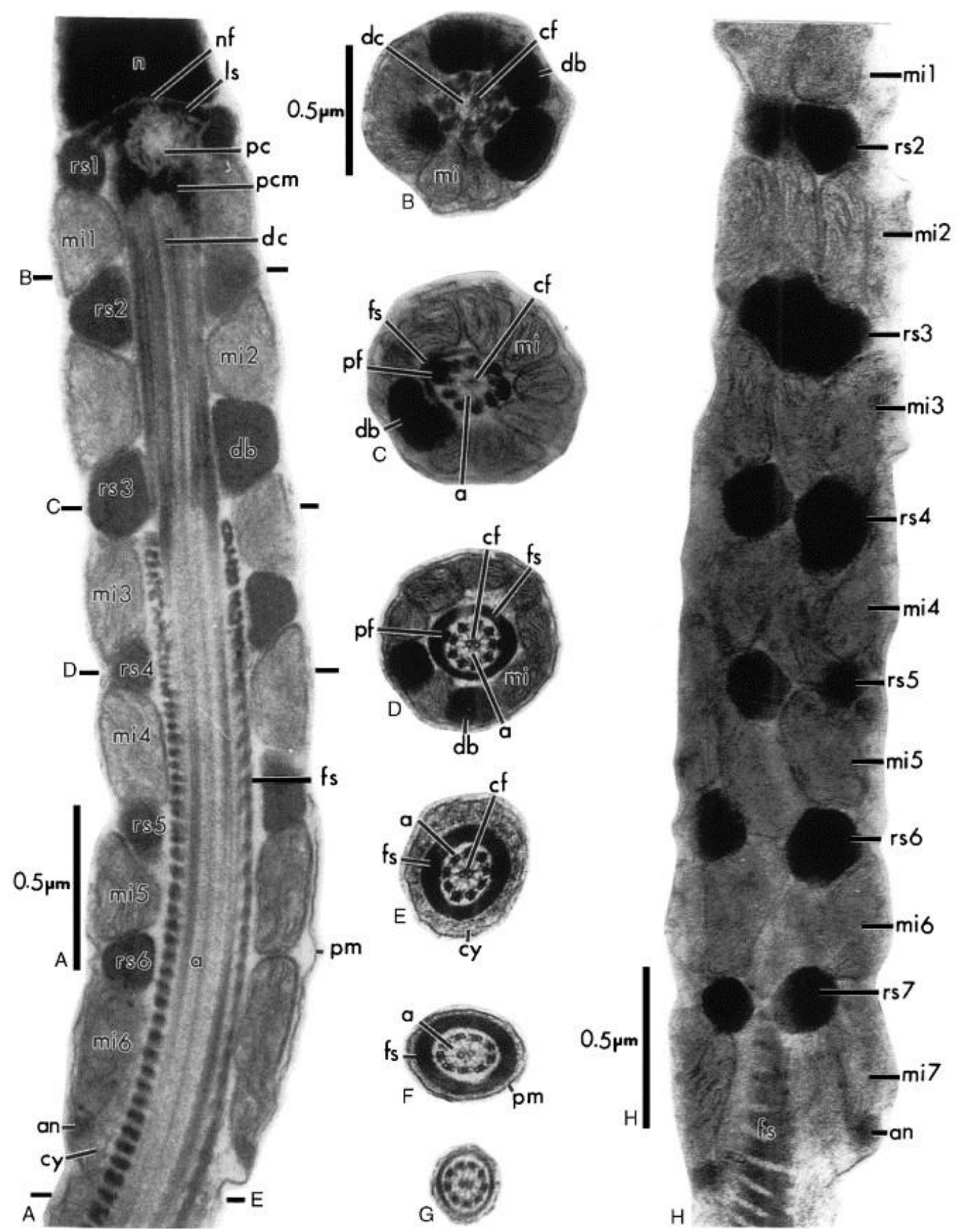

Fig. 4. Spermatozoa of C. amazonicus. A-H: Transmission electron micrographs of the tail (midpiece and principal piece). A: Longitudinal section (LS) through the midpiece showing neck region, the distal centriole, axoneme, fibrous sheath, mitochondria dense bodies, and annulus. (B-G) A series of transverse sections (TSs) through the sperm tail as indicated; (B) distal centriole showing the pair of central microtubules and the dense material within it; (C) the beginning of the axoneme showing the grossly enlarged fibers 3 and 8; (D) the axoneme showing that the peripheral fibers at 3 and 8 are thicker than the others and are detached from their doublets; (E) the anterior region of the principal piece; ( $F$ and $G$ ) the posterior end of the principal piece. $(H)$ LS through the midpiece showing the mitochondrial and dense body arrangement. Note the dense bodies are not fused within the ring structure. (B-G) To same scale as indicated: $a$, axoneme; an, annulus; $c f$, central fiber; cy, cytoplasm; db, dense bodies; dc, distal centriole; fs, fibrous sheath; Is, laminar structure; mi, mitochondrial tier; $n$, nucleus; nf, nuclear fossa; pc, proximal centriole; pf, peripheral fibers; pm, plasma membrane; pcm, pericentriolar material; $r s$, dense body ring structure. 


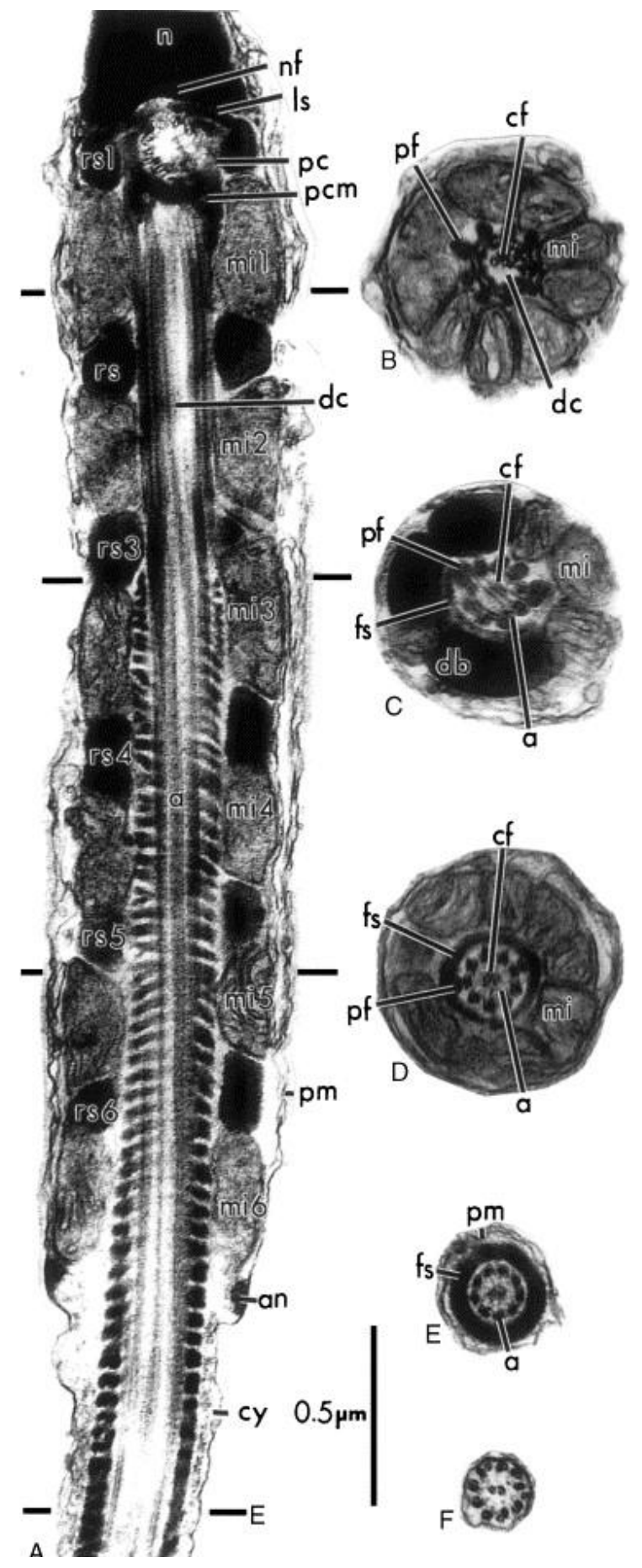

Fig. 5. Spermatozoa of D. guianensis. (A-F) Transmission electron micrographs of the tail (midpiece, principal piece and endpiece). (A) Longitudinal section (LS) of the entire midpiece length, showing neck region, the distal centriole, axoneme, fibrous sheath, mitochondria dense bodies, and annulus. (B-E) A series of transverse sections (TSs) through the sperm tail as indicated; (B) distal centriole showing the pair of central microtubules and the dense material within it; (C) the beginning of the axoneme showing the grossly enlarged fibers 3 and 8; (D) the axoneme showing that the peripheral fibers at 3 and 8 are thicker than the others and are detached from their doublets; $(E)$ the anterior region of the principal piece; (F) endpiece. (A-F) To same scale as indicated: a, axoneme; an, annulus; cf, central fiber; cy, cytoplasm; db, dense bodies; dc, distal centriole; fs, fibrous sheath; Is, laminar structure; mi, mitochondrial tier; $\mathrm{n}$, nucleus; $\mathrm{nf}$, nuclear fossa; $\mathrm{pc}$, proximal centriole; $\mathrm{pf}$, peripheral fibers; pm, plasma membrane; $p c m$, pericentriolar material; $r s$, dense body ring structure. 


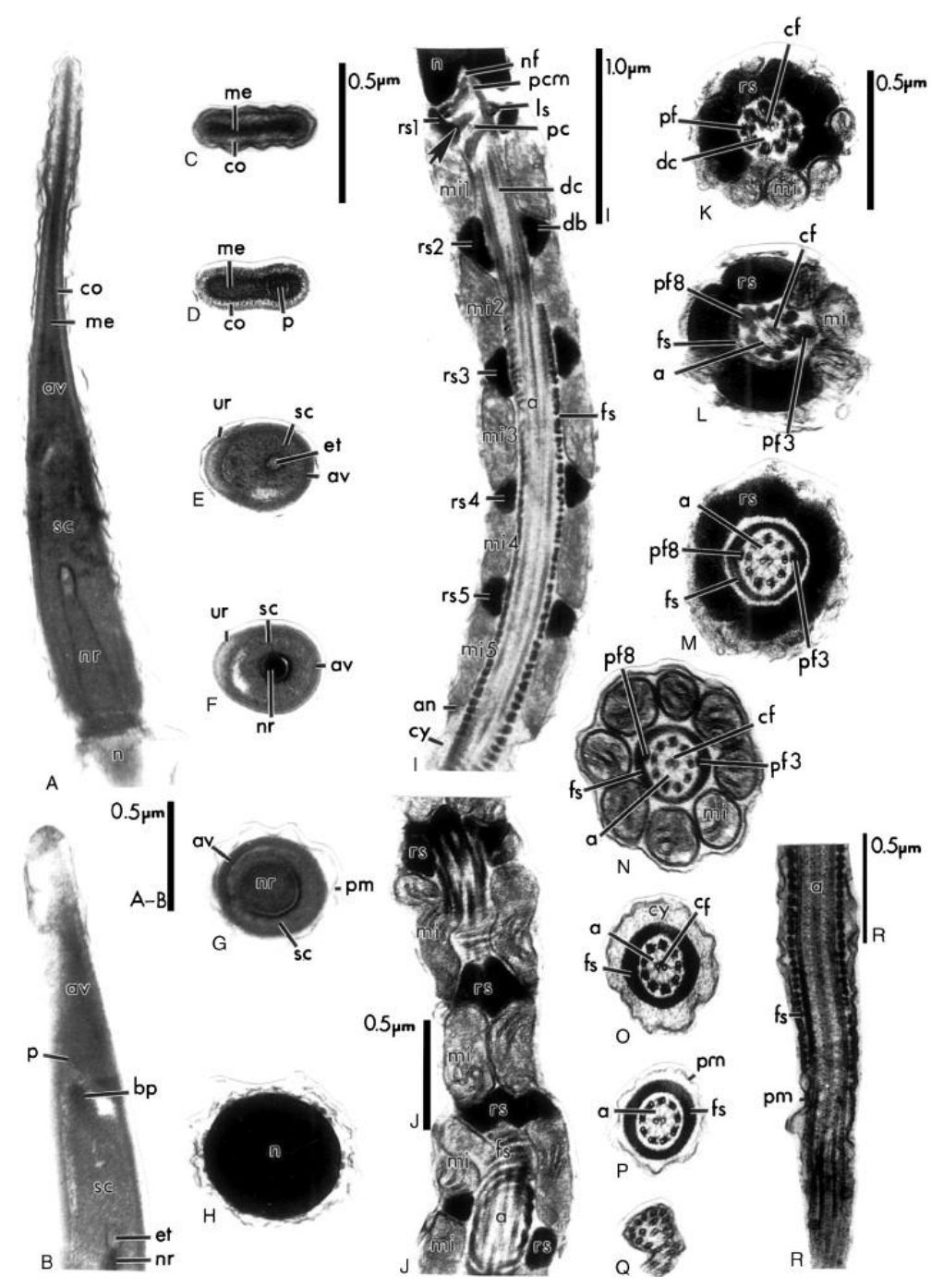

Fig. 6. Spermatozoa of T. oculatus. (A-R) Transmission electron micrographs. (A) Longitudinal section (LS) through the acrosome complex showing the acrosome vesicle with cortex and medulla, subacrosomal cone, nuclear rostrum, and electron-lucent zone. (B) LS of the acrosome complex showing its flattened appearance at anterior portion and the stopper-like base plate not embedded in the subacrosomal cone. (C-G) A series of transverse sections (TSs) through the spermatozoon as indicated. Note that anteriorly, in (C-D), the acrosome appears depressed, while posteriorly, in (E-F), it is unilaterally ridged and the electron-lucent region between the acrosome vesicle and the subacrosomal cone, and basally in (G), it appear more circular at its base. (H) TS through the nucleus. (I) LS of the full length of the midpiece showing the neck region with the nuclear fossa, pericentriolar material, centrioles, the stratified laminar structure, and five ring structures and five mitochondrial tiers. Arrow indicates the extension of dense body into center of the proximal centriole. $(J)$ Oblique section of the midpiece showing the mitochondrial and dense body arrangement. (K-Q) A series of TSs through the spermatozoon as indicated; $(K)$ through posterior portion of the distal centriole; $(L)$ through the dense body ring structure of the midpiece showing the grossly enlarged peripheral fibers 3 and 8 ; $(M)$ through the complete ring structure; $(\mathrm{N})$ through the axoneme showing peripheral fibers 3 and 8 thicker than the others, double and detached from their doublets; $(\mathrm{O}$ and $\mathrm{P})$ through anterior and posterior portion of the principal piece, respectively; $(Q)$ through the endpiece showing the disarranged microtubules pattern. (R) LS of the transition region between principal piece and the endpiece. ( $C-H$ and $K-Q$ ) To same scale as indicated. a: axoneme; an: annulus; av: acrosome vesicle; cf: central fiber; co: cortex; cy: cytoplasm; db: dense bodies; dc: distal centriole; et: epinuclear lucent zone; fs: fibrous sheath; Is: stratified laminar structure; m: mitochondrion; me: medulla; mi: mitochondrial tier; $\mathrm{n}$ : nucleus; $\mathrm{nf}$ : nuclear fossa; nr: nuclear rostrum; p: perforatorium; pb: perforatorial base plate; pc: proximal centriole; $\mathrm{pcm}$ : pericentriolar material; pf: peripheral fiber; pm: plasma membrane; rs: dense body ring structure; sc: subacrosomal cone; ur, unilateral ridge. 


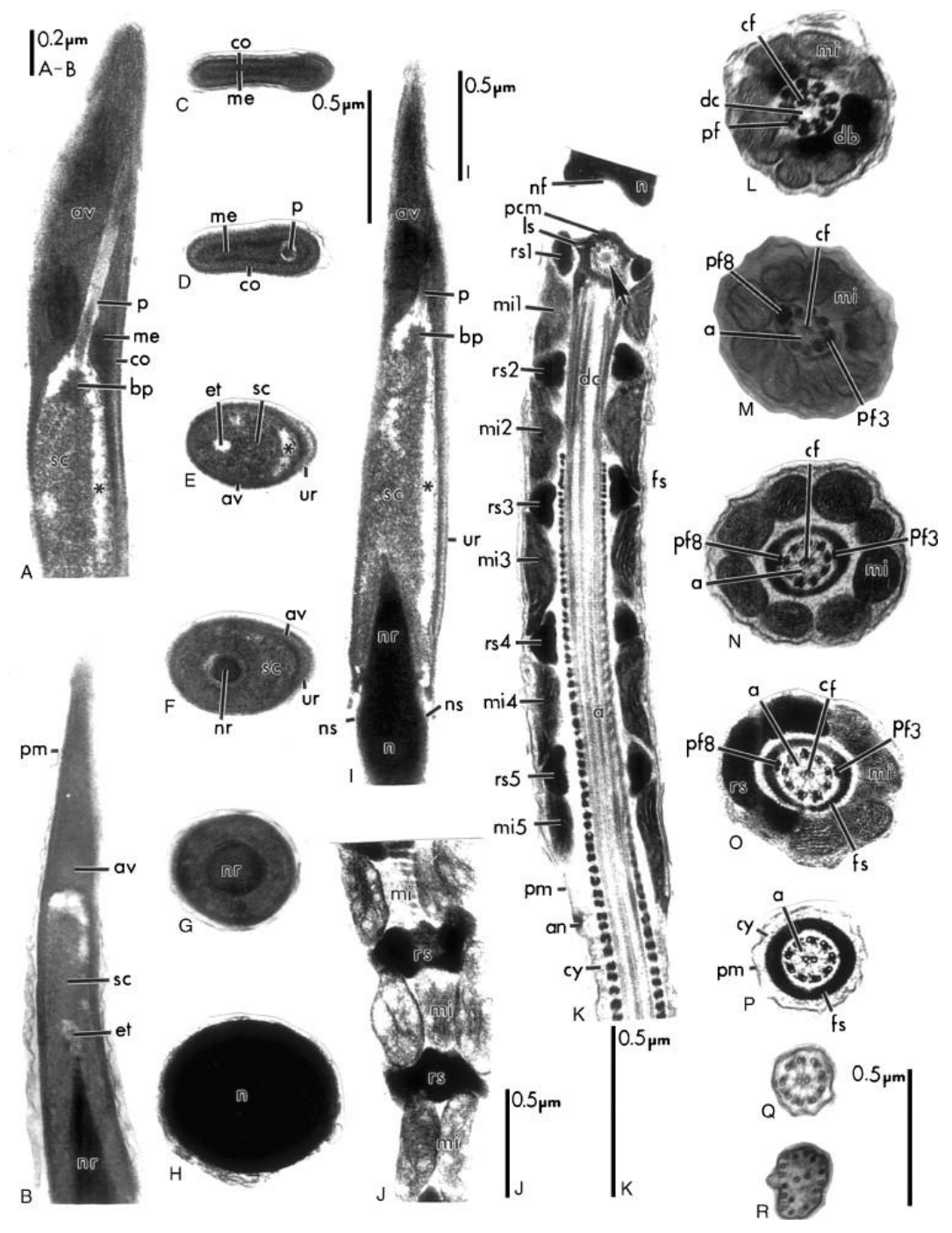

Fig. 7. Spermatozoa of D. guttulatum. (A-R) Transmission electron micrographs. (A) Longitudinal section (LS) through the acrosome complex showing the acrosome vesicle with cortex and medulla, subacrosomal cone, and stopper-like perforatorial base plate not embedded in the subacrosomal cone. (B) LS of the acrosome complex showing the epinuclear lucent zone. (C-G) A series of transverse sections (TSs) through the spermatozoon as indicated. Note that anteriorly, in (C-D), the acrosome appears depressed, while posteriorly, in (E-F), it is unilaterally ridged and the electron-lucent region between the acrosome vesicle and the subacrosomal cone, and in (G), it appear more circular at its base. (H) TS through the nucleus. (I) LS of the acrosome complex showing the nuclear rostrum and the unilateral ridge. $(\mathrm{J}) \mathrm{LS}$ of the midpiece showing the mitochondrial and dense body arrangement. (K) LS of the full length of the midpiece showing the neck region with the nuclear fossa, pericentriolar material, centrioles, the stratified laminar structure, and five ring structures and five mitochondrial tiers. Arrow indicates the dense body entering into the center of the proximal centriole. ( $L-R)$ A series of TSs through the spermatozoon as indicated; (L), through posterior portion of the distal centriole; (M) through axoneme showing the grossly enlarged peripheral fibers 3 and 8 ; $(\mathrm{N})$ through the axoneme showing peripheral fibers 3 and 8 thicker than the others, double and detached from their doublets, in (O), through the incomplete ring structure; $(P$ and $Q$ ) through anterior and posterior portion of the principal piece, respectively; $(R)$ through the endpiece showing the disarranged microtubules pattern. ( $C-H$ and $\mathrm{L}-\mathrm{R})$ To same scale as indicated. a: axoneme; an: annulus; av: acrosome vesicle; cf: central fiber; co: cortex; cy: cytoplasm; db: dense bodies; dc: distal centriole; et: epinuclear lucent zone; fs: fibrous sheath; Is: stratified laminar structure; m: mitochondrion; me: medulla; mi: mitochondrial tier; $\mathrm{n}$ : nucleus; nf: nuclear fossa; nr: nuclear rostrum; ns: nuclear shoulder; $p$ : perforatorium; pb: perforatorial base plate; pc: proximal centriole; pcm: pericentriolar material; pf: peripheral fiber; pm: plasma membrane; rs: dense body ring structure; sc: subacrosomal cone; ur, unilateral ridge. 

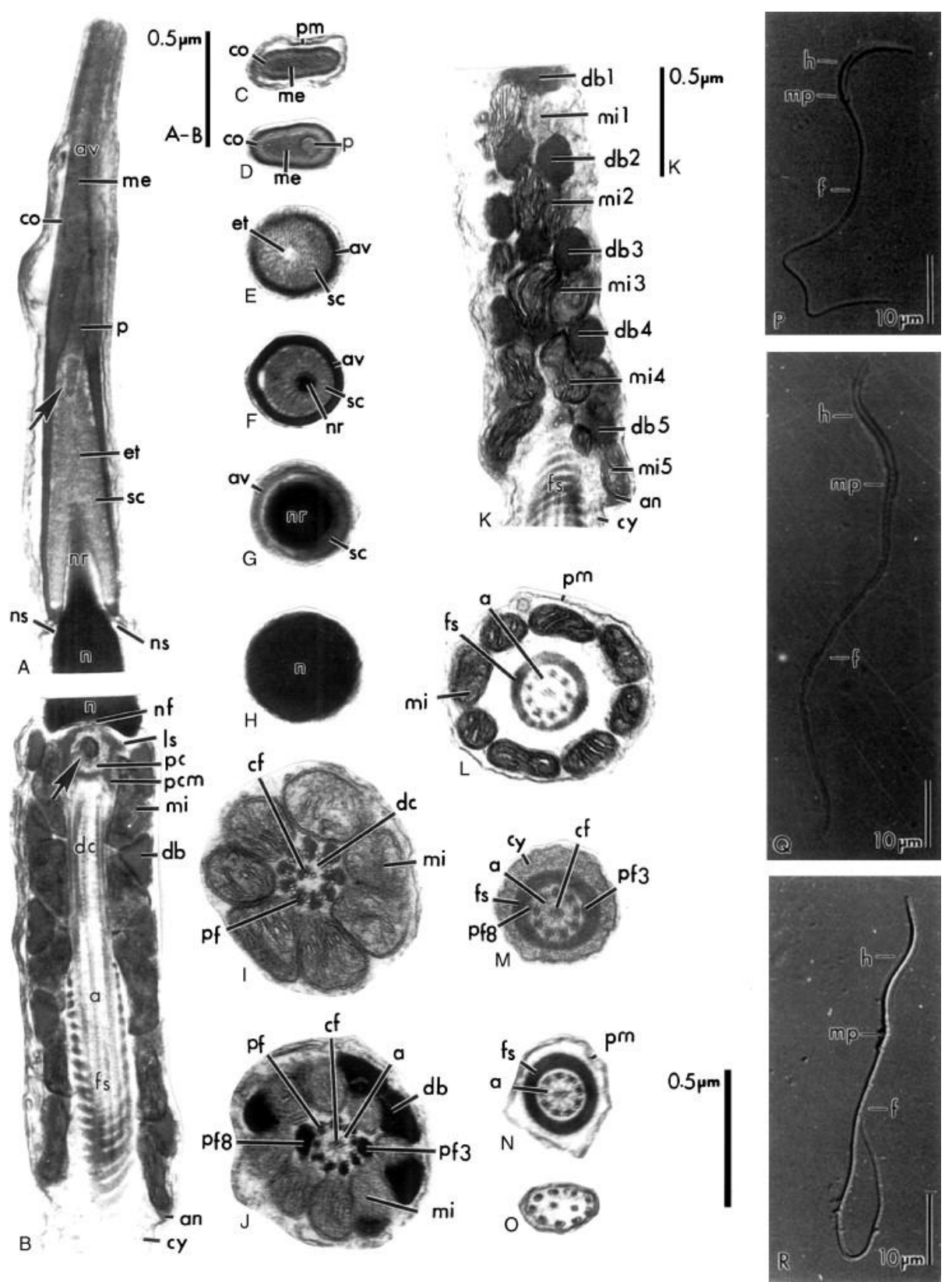

Fig. 8. Spermatozoa of C. ocellata. (A-O) Transmission electron micrographs. (A) Longitudinal section (LS) through the acrosome complex showing the acrosome vesicle, subacrosomal cone, and densification within the apex of the subacrosomal material (arrow). (B) LS of the full length of the midpiece showing the neck region with the nuclear fossa, pericentriolar material, centrioles, and the stratified laminar structure. Arrow indicates the dense body entering into the center of the proximal centriole. ( $C-J$ and $L-M)$ A series of transverse sections (TSs) through the spermatozoon as indicated. Note that anteriorly, in (C-D), the acrosome appears depressed, while posteriorly, in (E-G), it becomes circular at its base; $(\mathrm{H})$ through the nucleus; (I) through posterior portion of the distal centriole; (J) through axoneme showing the grossly enlarged peripheral fibers 3 and 8 ; $(L)$ through the axoneme showing peripheral fibers 3 and 8 thicker than the others, double and detached from their doublets; ( $M$ and $\mathrm{N}$ ) through anterior and posterior portion of the principal piece, respectively; $(\mathrm{O})$ through the endpiece showing the disarranged microtubules pattern. (K) $L S$ of the midpiece showing the five ring structures and five mitochondrial tiers. $(P-R)$ Light micrographs showing whole spermatozoon of $C$. ocellata (P), D. guttulatum (Q), and T. oculatus (R). ( $C-J$ and $L-O)$ To same scale as indicated. a: axoneme; an: annulus; av: acrosome vesicle; cf: central fiber; co: cortex; cy: cytoplasm; db: dense bodies; dc: distal centriole; et: epinuclear lucent zone; fs: fibrous sheath; h: head; Is: stratified laminar structure; m: mitochondrion; me: medulla; mi: mitochondrial tier; mp: midpiece; $\mathrm{n}$ : nucleus; nf: nuclear 
fossa; nr: nuclear rostrum; ns: nuclear shoulder; $p$ : perforatorium; pb: perforatorial base plate; pc: proximal centriole; pcm: pericentriolar material; pf: peripheral fiber; pm:plasma membrane; rs: dense body ring structure; sc: subacrosomal cone.

\subsection{Midpiece}

The midpiece lies at the anterior portion of the flagellum and includes the neck region at its anterior end. The midpiece begins with the first ring of dense bodies and ends posteriorly at a small annulus (Fig. 3, Fig. 4, Fig. 5, Fig. 6, Fig. 7 and Fig. 8). It consists of the axoneme surrounded by the fibrous sheath, mitochondrial tiers, and rings of dense bodies (ring structures) (Fig. 3, Fig. 4, Fig. 5, Fig. 6, Fig. 7 and Fig. 8).

The axoneme is the axial component of the midpiece and is composed of a pair of central microtubules (singlets) surrounded by nine doublets of microtubules, which are surrounded by nine peripheral dense fibers (Fig. 3, Fig. 4, Fig. 5, Fig. 6, Fig. 7 and Fig. 8). The central singlets of the axoneme extend anteriorly throughout the length of the distal centriole (Fig. 3, Fig. 4, Fig. 5, Fig. 6, Fig. 7 and Fig. 8). Associated with the two singlets is a central fiber, anteriorly located, closer to triplet 9; posteriorly it decreases in size and sits centrally between the axoneme singlets (Fig. 3, Fig. 4, Fig. 5, Fig. 6, Fig. 7 and Fig. 8). The central fiber disappears within the midpiece region. At the transition between the distal centriole and the axoneme, the peripheral fibers adjacent to doublets 3 and 8 are grossly enlarged, for a short distance (Fig. 3, Fig. 4, Fig. 5, Fig. 6, Fig. 7 and Fig. 8). In all species, the peripheral fibers rapidly decrease in diameter posteriorly, except fibers at doublets 3 and 8 , which are thicker and form a double structure separated from their corresponding doublet and closely associated with the fibrous sheath (Fig. 3, Fig. 4, Fig. 5, Fig. 6, Fig. 7 and Fig. 8). Posterior to the annulus, all nine peripheral fibers are vestigial or absent (Fig. 3, Fig. 4, Fig. 5, Fig. 6, Fig. 7 and Fig. 8).

In all teiid species analyzed, dense bodies are juxtaposed to the fibrous sheath in transverse section (Fig. 3, Fig. 4, Fig. 5, Fig. 6 and Fig. 7), whereas in C. ocellata, they are separated from the fibrous sheath by mitochondria ( Fig. 8J). In teiids, dense bodies form complete and incomplete rings, termed ring structures ( Fig. 3, Fig. 4, Fig. 6 and Fig. 7). In C. ocellata, dense bodies do not form ring structures, appearing as isolate dense structures ( Fig. 8K). In T. oculatus and D. guttulatum, inside ring structures, dense bodies appear as fused structures that occasionally occur in a spiral pattern ( Fig. 6 and Fig. 7), whereas in C. amazonicus, C. flavipunctatus, and D. guianensis dense bodies are not fused within ring structures ( Fig. 3 and Fig. 4). Longitudinally, columnar mitochondria occur in tiers that separate ring structures in teiids, but separate isolated dense rings in C. ocellata. 
Three sets of mitochondrial tiers and ring structures surround the axoneme in C. flavipunctatus ( Fig. 3A, B, I, J); five sets in D. guttulatum ( Fig. 7K), T. oculatus ( Fig. 6I), and C. ocellata ( Fig. 8K); whereas in C. amazonicus and D. guianensis six sets of mitochondrial tiers and ring structures are observed ( Fig. 4 and Fig. 5). In C. amazonicus, seven sets were occasionally observed in the midpiece ( Fig. 4H). The ring structure and mitochondrial arrangement pattern can be represented by the abbreviated expression $\mathrm{rs} 3 / \mathrm{mi} 3$ (previously expressed as $\mathrm{rs} 1 / \mathrm{mi} 1, \mathrm{rs} 2 / \mathrm{mi} 2, \mathrm{rs} 3 / \mathrm{mi} 3$ ) in C. flavipunctatus ( Fig. 3B, I); rs5/mi5 in D. guttulatum, T. oculatus, and C. ocellata ( Fig. 6, Fig. 7 and Fig. 8); and rs6/mi6 in C. amazonicus and D. guianensis ( Fig. 4 and Fig. 5). In the gymnophthalmid C. ocellata and the teiids C. flavipunctatus and D. guttulatum, mitochondria ( Fig. 3 and Fig. 7) extend anteriorly along the midpiece in a strictly columnar appearance; in longitudinal section they appear trapezoidal ( Fig. 3 and Fig. 7). In C. amazonicus and D. guianensis, mitochondria also have a strictly columnar appearance ( Fig. 4A), however, mitochondria ends have a symmetrical round shape ( Figs. 4H). In T. oculatus, columnar mitochondria have a regular, slightly curved appearance ( Fig. 6J), but are not arranged as sinuous tubes because they do not curve at an angle greater than $45^{\circ}$. In T. oculatus, the mitochondria appear trapezoidal in longitudinal section ( Fig. 6I, J).

The fibrous sheath encloses the axoneme and extends into the midpiece, reaching the base of the distal centriole (Fig. 3, Fig. 4, Fig. 5, Fig. 6, Fig. 7 and Fig. 8). In C. amazonicus, D. guianensis, and the gymnophthalmid C. ocellata, the fibrous sheath extends anteriorly into the midpiece to the level of mitochondrial tier 3 (mi3) ( Fig. 4, Fig. 5 and Fig. 8), occupying 63, 72, and $73 \%$ of the total midpiece length, respectively. In C. flavipunctatus, D. guttulatum, and T. oculatus, the fibrous sheath extends to the level of the second mitochondrial tier (mi2) ( Fig. 3, Fig. 6 and Fig. 7), occupying 68,85 , and $86 \%$ of the total midpiece length, respectively.

Posteriorly, the midpiece terminates at the annulus, which is closely attached to the inner surface of the plasma membrane. The annulus (Fig. 3, Fig. 4, Fig. 5, Fig. 6, Fig. 7 and Fig. 8 ) is a small dense ring with an irregular shape when viewed in longitudinal section.

\subsection{Principal piece}

The principal piece is the longest part of the spermatozoon and occurs posterior to the midpiece. It consists of the axoneme surrounded by fibrous sheath, cytoplasm, and plasma membrane. In this region, the central fiber, peripheral dense fibers, dense bodies, and mitochondria are all absent (Fig. 3, Fig. 4, Fig. 5, Fig. 6, Fig. 7 and Fig. 8). Within the anterior portion of the principal piece, immediately after the annulus, the diameter of the 
spermatozoon does not decrease relative to the annulus with the plasma membrane being widely separated from the fibrous sheath by a thick region of granular cytoplasm (Fig. 3, Fig. 4, Fig. 5, Fig. 6, Fig. 7 and Fig. 8). Posteriorly, the amount of cytoplasm decreases and the plasma membrane becomes closely associated with the fibrous sheath (Fig. 3, Fig. 4, Fig. 5, Fig. 6 and Fig. 8).

\subsection{Endpiece}

A short length of axoneme extends beyond the posterior limit of the fibrous sheath as the endpiece (Fig. 5, Fig. 7 and Fig. 8). The $9+2$ pattern of the axonemal microtubules is initially maintained, although their diameter is reduced. Posteriorly, the arrangement of microtubules becomes increasingly disrupted (Fig. 3, Fig. 6 and Fig. 7).

\subsection{Comparisons of spermatozoa ultrastructure and measurements}

The analyses of variance indicated that, except for the epinuclear lucent zone width (ETW), there were significant differences among species on the remaining 12 sperm dimensions (Table 2, Fig. 9, Fig. 10 and Fig. 11). Except for Crocodilurus and Dracaena, with no significant difference in sperm measurements, all species diverged in at least two measurements. Groups with homogeneous means varied from three (PPcy, ETL) to nine (HL) species for the distinct sperm measurements ( Fig. 9, Fig. 10 and Fig. 11). ESL and TL were the only two variables with a similar pattern across species, where Cercosaura and members of Teiinae tended to possess lower values than members of Tupinambinae. A cluster analysis of all teiid genera and Cercosaura, based on 13 sperm measurements ( Table 2), using the neighbor-joining method and Euclidean distances ( Table 3), with Cercosaura as outgroup, grouped species according to the two putative major groups of teiids, Teiinae and Tupinambinae, with the exception of Teius, which was placed more basally ( Fig. 12A). The greatest similarity in sperm measurements occurred between Dicrodon and Ameiva, and between Dracaena, Crocodilurus, and Tupinambis ( Table 3, Fig. 12A). Members of Tupinambinae (((Crocodilurus, Tupinambis) Dracaena), Callopistes) clustered together, as well as the "cnemidophorines" (sensu Reeder et al., 2002) Cnemidophorus, Kentropyx, and Aspidoscelis, but Ameiva, also a "cnemidophorine," was left out of this group and clustered with Dicrodon. 
Table 2

Sperm dimensions in teiid genera and in C. ocellata (Gymnophthalmidae)

\begin{tabular}{|c|c|c|c|c|c|c|}
\hline Characters & Ameiva & Aspidoscelis & Cnemidophorus & Dicrodon & Kentropyx & Teius \\
\hline $\mathrm{HL}$ & $16.78 \pm 1.38(6)$ & $10.83 \pm 0.29(3)$ & $13.30 \pm 0.61(14)$ & $15.60 \pm 1.38$ & $14.40 \pm 0.61(14)$ & $18.91 \pm 2.50(11)$ \\
\hline TL & $50.45 \pm 4.93(6)$ & $40.25 \pm 0.35$ & $40.13 \pm 2.82(7)$ & $54.01 \pm 4.72(2)$ & $53.64 \pm 2.81(8)$ & $53.20 \pm 6.96(10)$ \\
\hline ESL & $75.11 \pm 4.27(6)$ & $54.50 \pm 0.00(2)$ & $56.24 \pm 2.55(11)$ & $78.34 \pm 6.13$ & $75.58 \pm 2.50(10)$ & $74.74 \pm 10.73(10)$ \\
\hline MPL & $4.79 \pm 0.16$ & $3.48 \pm 0.03$ & $3.35 \pm 0.32(9)$ & $3.52 \pm 0.17(12)$ & $7.55 \pm 0.35(8)$ & $5.62 \pm 1.12(12)$ \\
\hline $\mathrm{AL}$ & $3.36 \pm 0.71(8)$ & $3.96 \pm 0.12(8)$ & $3.07 \pm 0.14(6)$ & $3.46 \pm 0.30(7)$ & $3.44 \pm 0.22(8)$ & $2.88 \pm 0.23(10)$ \\
\hline NBW & $0.47 \pm 0.06(14)$ & $0.68 \pm 0.04$ & $0.53 \pm 0.03(3)$ & $0.53 \pm 0.07$ & $0.64 \pm 0.03$ & $0.46 \pm 0.05(10)$ \\
\hline NRL & $0.87 \pm 0.9(15)$ & $0.77 \pm 0.03$ & $0.71 \pm 0.05(10)$ & $0.89 \pm 0.08(7)$ & $0.62 \pm 0.06(10)$ & $0.66 \pm 0.04(6)$ \\
\hline DCL & $0.90 \pm 0.10(5)$ & $0.92 \pm 0.12(6)$ & $0.72 \pm 0.07(7)$ & $0.85 \pm 0.25(12)$ & $0.65 \pm 0.03(7)$ & $0.86 \pm 0.09(10)$ \\
\hline ETL & $0.18 \pm 0.05(14)$ & $0.09 \pm 0.04(5)$ & $0.15 \pm 0.04(6)$ & $0.15 \pm 0.08(9)$ & $0.11 \pm 0.04$ & $0.11 \pm 0.04(6)$ \\
\hline ETW & $0.05 \pm 0.01$ & $0.05 \pm 0.01$ & $0.04 \pm 0.00$ & $0.05 \pm 0.02(10)$ & $0.04 \pm 0.01$ & $0.05 \pm 0.00(6)$ \\
\hline NSW & $0.33 \pm 0.03(7)$ & $0.50 \pm 0.03$ & $0.37 \pm 0.02$ & $0.39 \pm 0.02(11)$ & $0.42 \pm 0.03$ & $0.34 \pm 0.03(10)$ \\
\hline RD & $0.69 \pm 0.13$ & $1.00 \pm 0.00$ & $0.86 \pm 0.18$ & $0.76 \pm 0.06(12)$ & $0.95 \pm 0.01$ & $0.78 \pm 0.06(7)$ \\
\hline RC & $1.71 \pm 0.20$ & $1.78 \pm 0.24(3)$ & $1.89 \pm 0.22$ & $0.63 \pm 0.09$ & $1.96 \pm 0.06(2)$ & $0.63 \pm 0.09(7)$ \\
\hline Characters & Callopistes & \multicolumn{2}{|c|}{ Crocodilurus } & Dracaena & Tupinambis & Cercosaura \\
\hline $\mathrm{HL}$ & $16.81 \pm 2.22(12)$ & \multicolumn{2}{|c|}{$16.60 \pm 2.38(10)$} & $18.08 \pm 1.35(8)$ & $19.00 \pm 1.28(8)$ & $14.75 \pm 0.67(12)$ \\
\hline $\mathrm{TL}$ & $85.56 \pm 5.60(9)$ & \multicolumn{2}{|c|}{$63.85 \pm 2.08(9)$} & $66.66 \pm 1.84$ & $61.71 \pm 3.48$ & $50.57 \pm 2.61(13)$ \\
\hline ESL & $104.98 \pm 5.72(8)$ & \multicolumn{2}{|c|}{$84.98 \pm 3.06(9)$} & $90.50 \pm 3.41$ & $86.00 \pm 6.03(7)$ & $67.49 \pm 2.67(13)$ \\
\hline MPL & $1.82 \pm 0.12(19)$ & \multicolumn{2}{|c|}{$3.70 \pm 0.30(9)$} & $3.82 \pm 0.39$ & $3.59 \pm 0.14$ & $2.18 \pm 0.19$ \\
\hline $\mathrm{AL}$ & $2.99 \pm 0.12$ & \multicolumn{2}{|c|}{$3.51 \pm 0.22(7)$} & $3.15 \pm 0.22(5)$ & $3.89 \pm 0.42(9)$ & $2.83 \pm 0.20(9)$ \\
\hline NBW & $0.53 \pm 0.04(18)$ & \multicolumn{2}{|c|}{$0.51 \pm 0.05(19)$} & $0.47 \pm 0.05(12)$ & $0.51 \pm 0.02$ & $0.45 \pm 0.06(6)$ \\
\hline NRL & $0.65 \pm 0.10(12)$ & \multicolumn{2}{|c|}{$0.69 \pm 0.04(7)$} & $0.72 \pm 0.06(10)$ & $0.86 \pm 0.07$ & $0.57 \pm 0.10(5)$ \\
\hline DCL & $0.56 \pm 0.06(17)$ & \multicolumn{2}{|c|}{$1.04 \pm 0.16$} & $1.43 \pm 0.12$ & $1.10 \pm 0.00(2)$ & $0.73 \pm 0.04(2)$ \\
\hline ETL & $0.01 \pm 0.01(4)$ & \multicolumn{2}{|c|}{$0.13 \pm 0.04(6)$} & $0.12 \pm 0.02$ & $0.07 \pm 0.03$ & $0.11 \pm 0.04(6)$ \\
\hline ETW & $0.05 \pm 0.01$ & \multicolumn{2}{|c|}{$0.06 \pm 0.02$} & $0.05 \pm 0.01$ & $0.06 \pm 0.02$ & $0.05 \pm 0.00(6)$ \\
\hline NSW & $0.34 \pm 0.02(10)$ & $0.35 \pm$ & $.03(8)$ & \pm 0.03 & $0.39 \pm 0.03$ & $0.33 \pm 0.03(3)$ \\
\hline $\mathrm{RD}$ & $0.75 \pm 0.07(19)$ & $0.67 \pm$ & $.08(12)$ & \pm 0.10 & $0.80 \pm 0.04$ & $0.66 \pm 0.09(5)$ \\
\hline RC & $1.52 \pm 0.22(19)$ & $1.64 \pm$ & $.20(12)$ & \pm 0.33 & $1.75 \pm 0.12(4)$ & $0.48 \pm 0.09(2)$ \\
\hline
\end{tabular}

Note: $\mathrm{HL}$, head length; TL, tail length; ESL, entire sperm length; MPL, midpiece length; $\mathrm{AL}$, acrosome length; NBW, nuclear base width; NRL, nuclear rostrum length; $D C L$, distal centriole length; $E T L$, epinuclear lucent zone length; ETW, epinuclear lucent zone width; NSW, nuclear shoulders width; RD, ratio of anterior principal piece diameter to midpiece diameter; RC, ratio of anterior principal piece diameter to fibrous sheath diameter.

Table 3

Matrix of Euclidean distances between teiid genera and Cercosaura (Gymnophthalmidae), based on 13 measurements of the sperm cell

\begin{tabular}{|c|c|c|c|c|c|c|c|c|c|c|c|}
\hline Genus & Ame & Asp & Cne & Dic & Ken & $T e i$ & $\mathrm{Cal}$ & $\mathrm{Cro}$ & Dra & Tup & $\mathrm{Cer}$ \\
\hline Ameiva & 0.00 & 6.40 & 3.81 & 2.75 & 5.30 & 3.63 & 6.11 & 3.09 & 3.63 & 4.01 & 4.61 \\
\hline Aspidoscelis & 6.40 & 0.00 & 4.84 & 5.35 & 4.74 & 7.09 & 7.86 & 6.23 & 7.67 & 5.87 & 7.11 \\
\hline Cnemidophorus & 3.81 & 4.84 & 0.00 & 4.09 & 4.03 & 4.53 & 6.38 & 5.00 & 5.64 & 5.91 & 4.24 \\
\hline Dicrodon & 2.75 & 5.35 & 4.09 & 0.00 & 5.24 & 3.63 & 5.63 & 3.49 & 4.55 & 3.83 & 4.16 \\
\hline Kentropyx & 5.30 & 4.74 & 4.03 & 5.24 & 0.00 & 5.11 & 6.39 & 5.56 & 6.46 & 6.02 & 6.24 \\
\hline Teius & 3.63 & 7.09 & 4.53 & 3.63 & 5.11 & 0.00 & 5.20 & 3.75 & 4.15 & 4.78 & 3.13 \\
\hline Callopistes & 6.11 & 7.86 & 6.38 & 5.63 & 6.39 & 5.20 & 0.00 & 4.70 & 5.25 & 5.21 & 5.09 \\
\hline Crocodilurus & 3.09 & 6.23 & 5.00 & 3.49 & 5.56 & 3.75 & 4.70 & 0.00 & 2.81 & 2.82 & 4.23 \\
\hline Dracaena & 3.63 & 7.67 & 5.64 & 4.55 & 6.46 & 4.15 & 5.25 & 2.81 & 0.00 & 4.07 & 4.90 \\
\hline Tupinambis & 4.01 & 5.87 & 5.91 & 3.83 & 6.02 & 4.78 & 5.21 & 2.82 & 4.07 & 0.00 & 5.92 \\
\hline Cercosaura & 4.61 & 7.11 & 4.24 & 4.16 & 6.24 & 3.13 & 5.09 & 4.23 & 4.90 & 5.92 & 0.00 \\
\hline
\end{tabular}




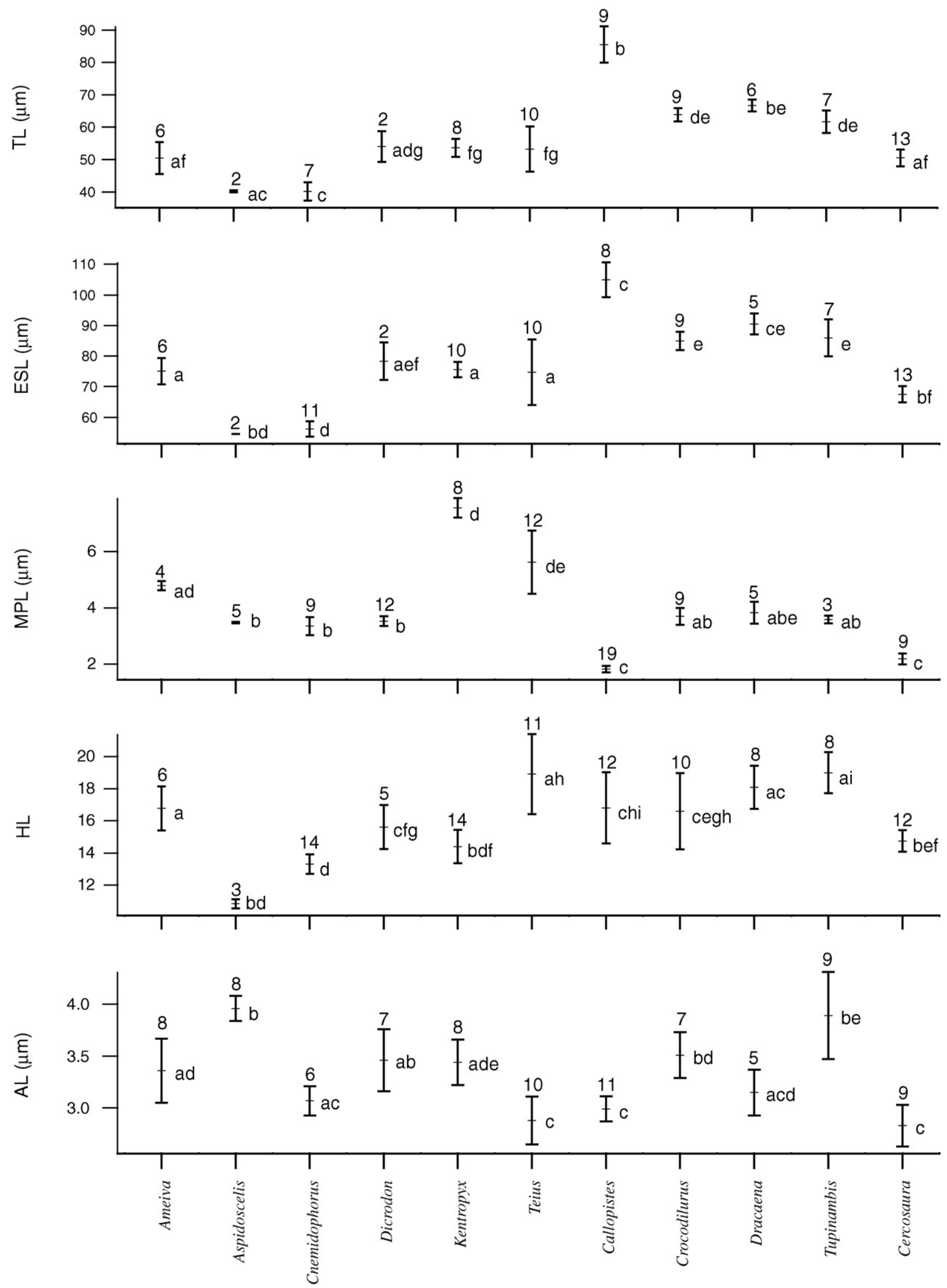

Fig. 9. Sperm dimensions in reid genera and C. ocellata (Gymnophthalmidae). Bars represent means \pm 1S.D. and sample size is indicated above each bar. Different letters represent significant differences at the 5\% level using Tukey's HSD test. TL: tail length, ESL: entire sperm length, MPL: midpiece length, HL: head length, AL: acrosome length. 

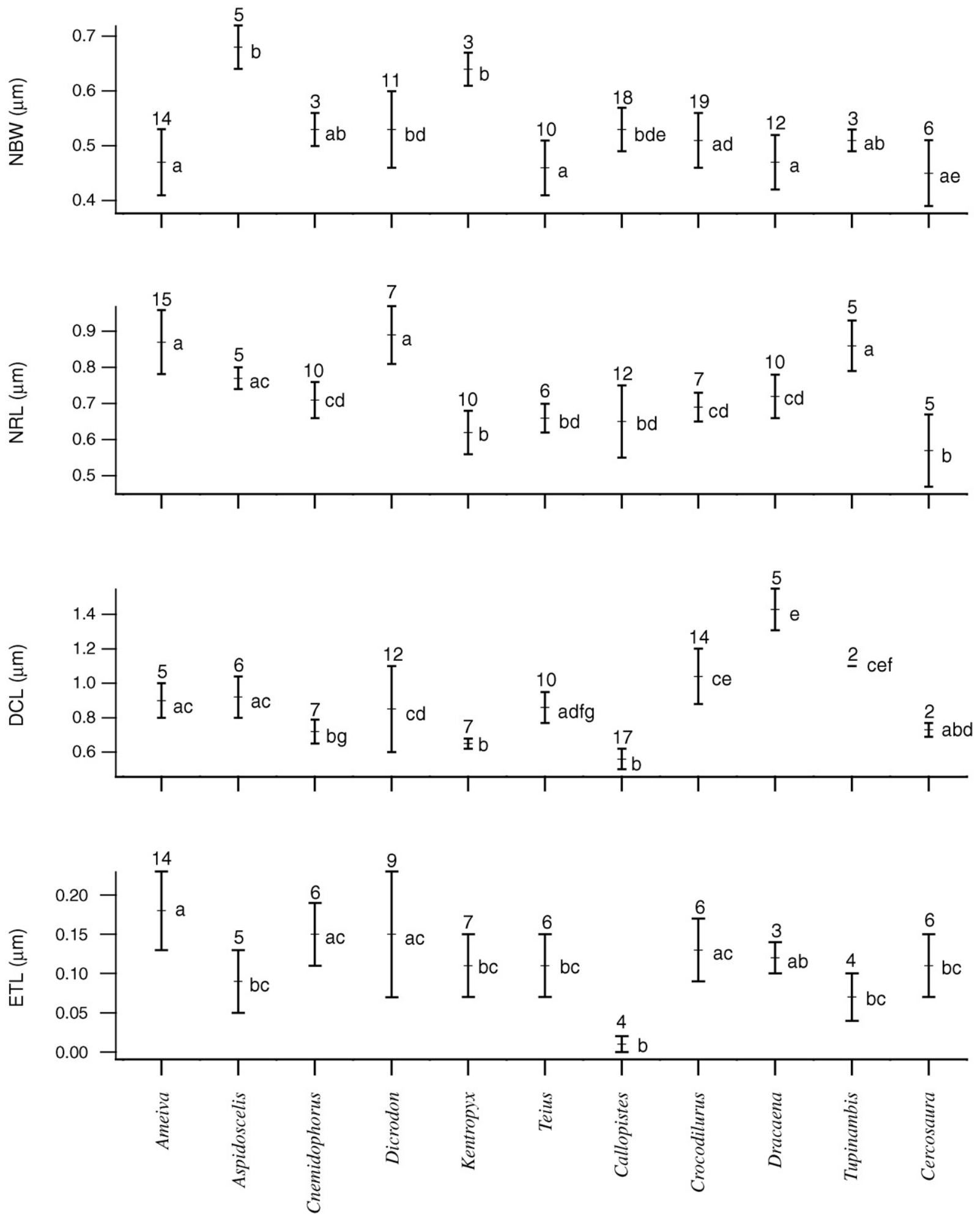

Fig. 10. Sperm dimensions in teiid genera and C. ocellata (Gymnophthalmidae). Bars represent means \pm 1 S.D. and sample size is indicated above each bar. Different letters represent significant differences at the 5\% level using Tukey's HSD test. NBW: nuclear base width, NRL: nuclear rostrum length, DCL: distal centriole length, ETL: epinuclear lucent zone. 

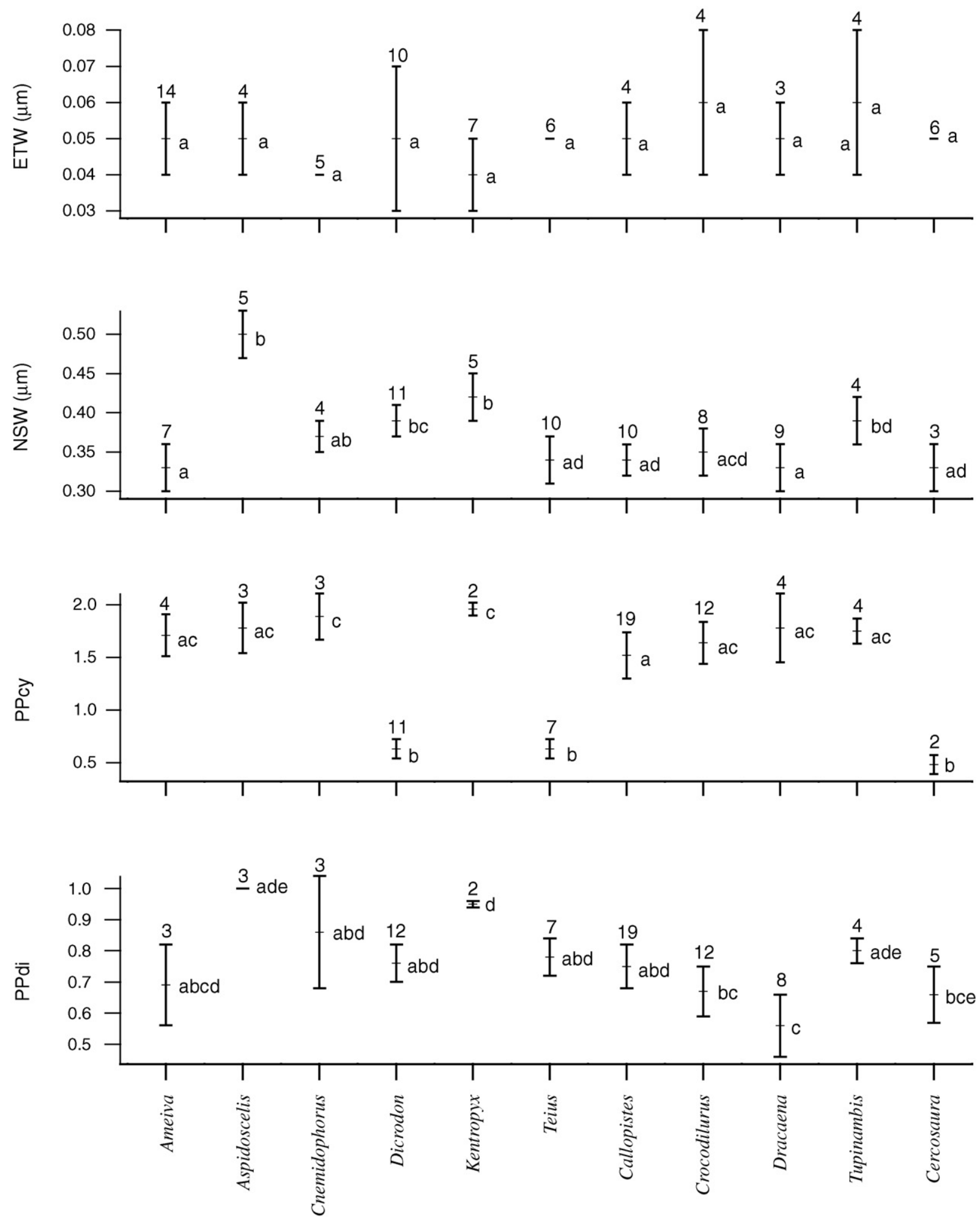

Fig. 11. Sperm dimensions in teiid genera and C. ocellata (Gymnophthalmidae). Bars represent means \pm 1 S.D. and sample size is indicated above each bar. Different letters represent significant differences at the 5\% level using Tukey's HSD test. ETW: epinuclear lucent width, NSW: nuclear shoulders width, PPcy: amount of cytoplasm between fibrous sheath and plasma membrane at the anterior region of the principal piece, PPdi: degree of reduction of the diameter between the posterior portion of the midpiece and the anterior portion of the principal piece. 

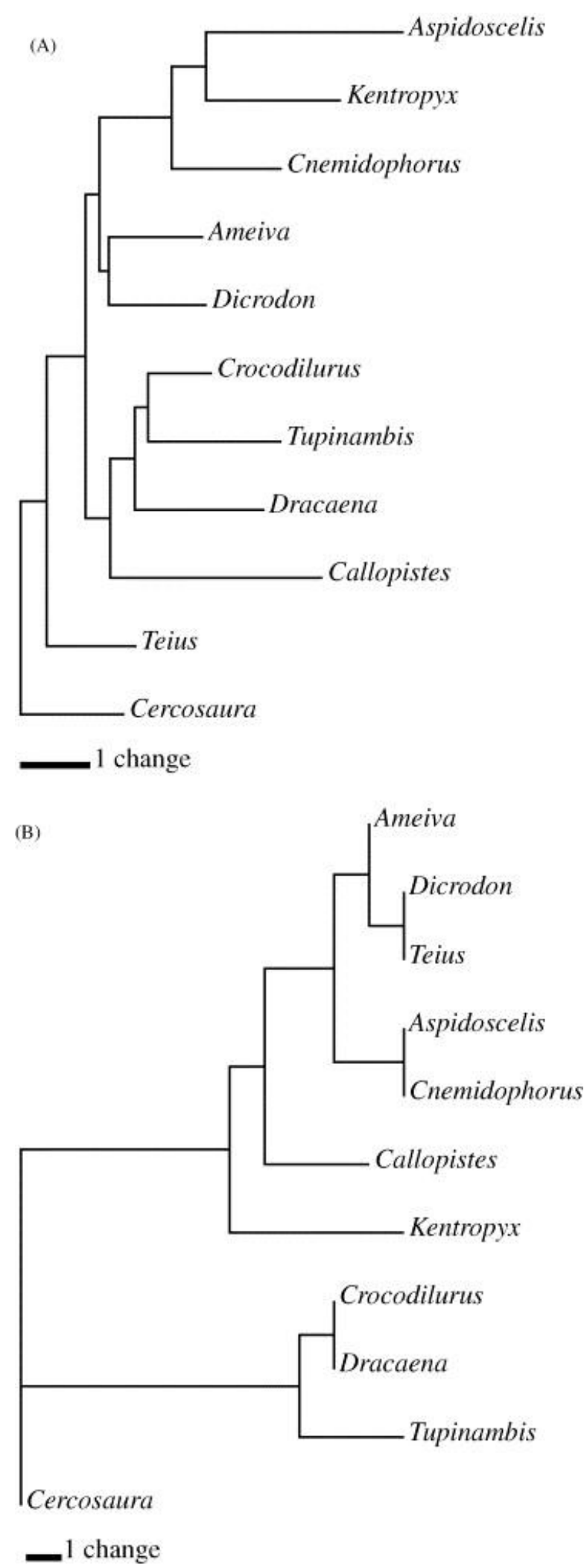

Fig. 12. (A) clustering of teiid genera and C. ocellata, based on 13 measurements of the sperm cell, and produced with Euclidean distances and neighbor-joining. (B) clustering of teiid genera and C. ocellata, based on 16 discrete characters of the sperm cell, based on mean character differences and neighborjoining. 
A cluster analysis of all teiid genera and Cercosaura, based on 16 discrete sperm characters ( Table 1), using the neighbor-joining method and mean character difference distances ( Table 4), with Cercosaura as outgroup, also grouped species according to the two putative major groups of teiids, Teiinae and Tupinambinae, with the exception of Callopistes, which was placed within Teiinae ( Fig. 12B). The greatest similarity in sperm characters occurred between Ameiva and all other Teiinae (only one character difference), with the exception of Kentropyx ( Table 4, Fig. 12B). The large Tupinambinae ((Crocodilurus, Dracaena) Tupinambis) clustered together, as well as the "cnemidophorines" Cnemidophorus, and Aspidoscelis. However, Ameiva and Kentropyx, also "cnemidophorines," were left out of this group and clustered, respectively, with (Dicrodon, Teius) and (Callopistes, remaining Teiinae).

Table 4

Matrix of mean character difference distances between teiid genera and Cercosaura (Gymnophthalmidae), based on 16 discrete characters of the sperm cell

\begin{tabular}{|c|c|c|c|c|c|c|c|c|c|c|c|}
\hline Genus & Ame & Asp & Cne & Dic & Ken & $T e i$ & Cal & Cro & Dra & Tup & $\mathrm{Cer}$ \\
\hline Ameiva & - & 0.06 & 0.06 & 0.06 & 0.27 & 0.06 & 0.13 & 0.31 & 0.31 & 0.31 & 0.64 \\
\hline Aspidoscelis & 1 & - & 0 & 0.13 & 0.33 & 0.13 & 0.19 & 0.38 & 0.38 & 0.25 & 0.71 \\
\hline Cnemidophorus & 1 & 0 & - & 0.13 & 0.33 & 0.13 & 0.19 & 0.38 & 0.38 & 0.25 & 0.71 \\
\hline Dicrodon & 1 & 2 & 2 & - & 5 & 0 & 0.19 & 0.38 & 0.38 & 0.38 & 0.71 \\
\hline Kentropyx & 4 & 5 & 5 & 0.33 & - & 0.33 & 0.40 & 0.40 & 0.40 & 0.47 & 0.71 \\
\hline Teius & 1 & 2 & 2 & 0 & 5 & - & 0.19 & 0.38 & 0.38 & 0.38 & 0.71 \\
\hline Callopistes & 2 & 3 & 3 & 3 & 6 & 3 & - & 0.25 & 0.25 & 0.25 & 0.71 \\
\hline Crocodilurus & 5 & 6 & 6 & 6 & 6 & 6 & 4 & - & 0 & 0.25 & 0.64 \\
\hline Dracaena & 5 & 6 & 6 & 6 & 6 & 6 & 4 & 0 & - & 0.25 & 0.64 \\
\hline Tupinambis & 5 & 4 & 4 & 6 & 7 & 6 & 4 & 4 & 4 & - & 0.71 \\
\hline Cercosaura & 9 & 10 & 10 & 10 & 10 & 10 & 10 & 9 & 9 & 10 & - \\
\hline
\end{tabular}

Above diagonal, mean character differences; below diagonal, total character differences

In summary, there was greater agreement between continuous and discrete sperm characters for clustering together Crocodilurus, Dracaena, and Tupinambis, suggesting greatest overall similarity in sperm morphology among these genera. In spite of being similar in all qualitative ultrastructural characters, Cnemidophorus and Aspidoscelis presented significant differences in both acrosome and distal centriole lengths ( Fig. 9 and Fig. 10). Likewise, Dicrodon and Teius diverged in lengths of midpiece, head, acrosome, nuclear rostrum, and widths of nuclear base and nuclear shoulders, despite being very similar in qualitative characters.

\section{Discussion}

In all teiid genera, Ameiva ( Giugliano et al., 2002), Cnemidophorus, Aspidoscelis, Kentropyx ( Teixeira et al., 2002), Tupinambis ( Tavares-Bastos et al., 2002), Dracaena, Crocodilurus, Callopistes, Teius, and Dicrodon, and the gymnophthalmids Micrablepharus maximiliani ( Teixeira et al., 1999b) and C. ocellata (this study), the acrosome complex is 
arranged in a tripartite pattern (acrosome vesicle, subacrosomal cone, and the constricted nuclear tip), a putative plesiomorphy of Tetrapoda ( Jamieson, 1995a). The following features, regarded as plesiomorphic in Amniota ( Jamieson, 1995b) are also seen in all Teiidae and Gymnophthalmidae studied: nucleus elongate; distal centriole extending into the midpiece and being penetrated by the central singlets of the axoneme; several mitochondria observed in cross section of midpiece; annulus present; nine peripheral fibers associated with the nine doublets of the axoneme; and peripheral fibers adjacent to doublets 3 and 8 enlarged, forming a double structure detached from their respective doublet. Likewise, putative synapomorphies of Squamata ( Jamieson, 1995a) are also seen in all Teiidae and Gymnophthalmidae investigated to date, including: perforatorium single, wholly prenuclear; endonuclear canal absent; epinuclear lucent zone present; mitochondrial cristae linear; intermitochondrial dense bodies present; fibrous sheath extending into midpiece; and nuclear shoulders presence at the transition from the nuclear rostrum to the cylindrical portion of the nucleus. These findings reinforce the synapomorphies mentioned above and highlight the usefulness of sperm ultrastructure characters in phylogenetic analyses ( Jamieson, 1995a, Jamieson, 1995b, Oliver et al., 1996, Teixeira et al., 1999a and Teixeira et al., 1999b).

In the acrosome complex, several differences were recorded among teiid genera as well as between teiids and gymnophthalmids. A unilateral ridge is present in the acrosome surface of all teiid genera, but is absent in Cercosaura and Micrablepharus ( Teixeira et al., 1999b). Likewise, in all teiids the cortex of the acrosome vesicle has a tubular organization; however, this feature is absent in Cercosaura and Micrablepharus. A perforatorial base plate was observed in all teiids but Kentropyx ( Teixeira et al., 2002), and is absent in Cercosaura and Micrablepharus. However, Teixeira et al. (2002) reported a slight densification in the subacrosomal cone apex of Kentropyx, but did not consider it a perforatorial base plate. This densification was also observed in Cercosaura. Of the genera that possess a perforatorial base plate, only Tupinambis ( Tavares-Bastos et al., 2002) has a knob-like shaped base plate; all other teiid genera have a stopper-like shaped base plate. With the exception of Dicrodon and Teius, the base plate is embedded in the apex of the subacrosomal material in Teiidae and Gymnophthalmidae. Spermatozoa of Teiidae and Gymnophthalmidae share several features: acrosome depressed and flattened anteriorly, becoming circular posteriorly; acrosome vesicle divided into medulla and cortex anteriorly; perforatorium (anteriorly) observed outside the central third of the flattened acrosome; and presence of the epinuclear lucent zone.

Within the neck region, the laminar structure is well developed in teiids and Micrablepharus ( Teixeira et al., 1999b), projecting from both sides of the proximal centriole, whereas in Cercosaura it is poorly developed and projects unilaterally from one side of the 
proximal centriole. A short, solid cylinder of electron-dense material, extending from the first dense body ring structure into the center of the proximal centriole, is present in all teiids (except Crocodilurus and Dracaena) but absent from Cercosaura and Micrablepharus.

In the midpiece, dense bodies are separated by mitochondrial tiers, this arrangement being a common feature of Teiidae and Gymnophthalmidae. However, major variability in the finer detail of this arrangement occurs both within Teiidae, as well as between Teiidae and Gymnophthalmidae, the same happening with other aspects of the midpiece. In all teiids and gymnophthalmids, with the exception of Aspidoscelis, Cnemidophorus, and Tupinambis, peripheral fibers are grossly enlarged for a short distance, at the level of the distal centriole/axoneme. In Teiinae, dense body and mitochondrial tiers form five sets; in Tupinambinae, three or six sets of dense bodies and mitochondrial tiers are present; whereas in Gymnophthalmidae there are four sets in Micrablepharus ( Teixeira et al., 1999b) and five in Cercosaura. Kentropyx is the only genera studied with slightly curved, instead of strictly columnar mitochondria. In longitudinal section, mitochondria have a trapezoidal shape in all teiids and gymnophthalmids, except in Dracaena and Crocodilurus, where mitochondria have rounded ends. In all teiids, dense bodies form ring structures around, and are directly juxtaposed to, the fibrous sheath, whereas in Gymnophthalmidae dense bodies do not form ring structures and are not juxtaposed to the fibrous sheath. In Teiinae, dense bodies are fused into ring structures, whereas in Tupinambinae dense bodies are not fused. The fibrous sheath begins at the first mitochondrial tier level in Kentropyx (Teixeira et al., 2002), at the second mitochondrial tier level in other Teiinae and Callopistes, and at the third mitochondrial tier level in other Tupinambinae and Gymnophthalmidae.

Within the principal piece, the absence of all nine dense fibers and the presence of cytoplasm between the fibrous sheath and the plasma membrane immediately posterior to the annulus are shared by Teiidae and Gymnophthalmidae. In the endpiece, the disrupted arrangement of microtubules at its posterior portion is observed in the Teiidae and Cercosaura. No variability was found within these two regions of the sperm cell.

In Boulenger's Catalogues, the basis of modern herpetology (Vanzolini, 1977), teiids and gymnophthalmids were grouped in a single family, Teiidae (Boulenger, 1885). Ruibal (1952) divided Teiidae in two groups, one containing the large-bodied genera, commonly called macroteiids (=Teiidae), and another containing the remaining genera, called microteiids (=Gymnophthalmidae). Presch (1983) confirmed this arrangement based on morphological data, placing microteiids in Gymnophthalmidae and macroteiids in Teiidae. However, his scheme is not widely accepted (e.g., Harris, 1985 and Myers and Donnelly, 2001). Our results detected a suite of characters from the mature sperm that distinguishes Teiidae from 
Gymnophthalmidae, including unilateral ridge present in acrosome surface (absent), dense bodies forming ring structures around the axoneme (no ring structures), and dense bodies juxtaposed to the fibrous sheath (not juxtaposed), thus corroborating Presch's scheme.

A number of morphological characters support the division of Teiidae (sensu Presch) into two groups, Teiinae and Tupinambinae, including external morphology ( Vanzolini and Valencia, 1965), chromosomes (Gorman, 1970), osteology (Presch, 1974 and Veronese and Krause, 1997), and myology ( Rieppel, 1980). In support of this view, we identified two unique traits distinguishing Teiinae from Tupinambinae: presence of five sets of mitochondrial tiers and ring structures, and dense bodies fused in the ring structures in the Teiinae. Further, the statistical analysis of the dimensions of 13 sperm measurements clustered together members of Tupinambinae, indicating high similarity in these characters.

Although the sperm of Cnemidophorus and Aspidoscelis were similar in all discrete ultrastructural characters, statistical analyses of sperm dimensions revealed significant differences in acrosome and distal centriole lengths between the two genera. These results support Reeder et al.'s (2002) hypothesis that the lemniscatus species-group and Cnemidophorus groups from North America belong to two different genera. Further, according to both discrete and continuous sperm ultrastructure features, Ameiva and Dicrodon are very similar.

Our results revealed high levels of inter-generic variability in sperm ultrastructure within Teiidae, corroborating previous suggestions that intra-familial, and even intra-generic, variability in these characters may be higher than currently thought (Teixeira et al., 1999a, Teixeira et al., 1999b, Giugliano et al., 2002 and Tavares-Bastos et al., 2002). Although ideal characters in phylogenetic analyses should vary between terminal units, but not vary within them (Thiele, 1993), many characters often vary within species or aggregates of species (e.g., genera, families) (Poe and Wiens, 2000). Systematists may use a variety of methods for dealing with this variation, including (1) breaking up the terminal taxon into smaller, invariant units, (2) excluding variable characters, and (3) using different methods for inclusion and coding of variable characters (Wiens, 1995). Simulations and empirical data suggest strongly that breaking up higher taxa and using species as terminal units will give more accurate estimates of phylogeny than will using methods of coding polymorphic traits, coding higher taxa as terminals, or excluding characters that vary within them (Wiens, 1998 and Wiens, 2000). Therefore, sampling multiple species within teiid genera is essential for use in phylogenetic analyses at the generic level. Further, the use of sperm measurements may profitably complement qualitative ultrastructural characters, maximizing the information content of these structures in phylogenetic analyses. 
Acknowledgments

We thank the following individuals and institutions for loan of specimens: Elias Ponce (MNHN), Herman Nuñez (MHN), Omar Pesantes, Marcos Di Bernardo (PUCRS), Sonia Cechin (ZUFSM), and Jardim Botânico de Porto Alegre (MCN). We thank Fernanda Werneck, and Adrian A. Garda, for assistance with character coding, and Daniel Diniz, Renato G. Faria, Mariana Zatz, Elias Ponce, and Herman Nuñez for assistance during fieldwork. Patrick Stephens, John Rawlins and Victor Becker provided insightful criticisms on the manuscript. This study was supported by doctorate fellowships from CAPES to DOM and RDT, and from CNPq to HCW; by research fellowships from CNPq to GRC (\#302343/88-1) and to SNB (\# 500483/2003-5); and by a postdoctoral fellowship from CNPq to DOM (\# 150296/2005-3).

\section{References}

Boulenger, G.A., 1885. Catalogue of the Lizards in the British Museum (Natural History). Volume II. Iguanidae, Xenosauridae, Zonuridae, Anguidae, Anniellidae, Helodermatidae, Varanidae, Xantusiidae, Teiidae, Amphisbaenidae. Trustees of the British Museum of Natural History, London, 497 pp.

Giugliano, L.G., Teixeira, R.D., Colli, G.R., Bao, S.N., 2002. Ultrastructure of spermatozoa of the lizard A. ameiva, with considerations on polymorphism within the family Teiidae (Squamata). J. Morphol. 253, 264-271.,

Gorman, G.C., 1970. Chromosomes and the systematics of the family Teiidae. Copeia 1970, 230-245.

Harris, D.M., 1985. Infralingual plicae: support for Boulenger's Teiidae (Sauria). Copeia 1985, 560-565.

Jamieson, B.G.M., 1995a. The ultrastructure of spermatozoa of the Squamata (Reptilia) with phylogenetic considerations. In: Jamieson, B.G.M., Ausio, J., Justine, J. (Eds.), Advances in Spermatozoal Phylogeny and Taxonomy. Museum National d'Histoire Naturelle, Paris, France, pp. 359-383.

Jamieson, B.G.M., 1995b. Evolution of tetrapod spermatozoa with particular reference to amniotes. In: Jamieson, B.G.M., Ausio, J., Justine, J. (Eds.), Advances in Spermatozoal Phylogeny and Taxonomy. Museum National ' d'Histoire Naturelle, Paris, France, pp. 343-358.

Moro, S., Abdala, V., 2000. Cladistic analysis of Teiidae (Squamata) based on myological characters. Russian J. Herpetol. 7, 87-102.

Myers, C.W., Donnelly, M.A., 2001. Herpetofauna of the Yutaje-Corocoro massif, Venezuela: Second report from The Robert G. Goelet American Museum-terramar expedition to the northwestern tepuis. B. Am. Mus. Nat. Hist., 1-85.

Newton, W.D., Trauth, S.E., 1992. Ultrastructure of the spermatozoon of the lizard Cnemidophorus sexlineatus (Sauria: Teiidae). Herpetologica 48, 330-343. 
Oliver, S.C., Jamieson, B.G.M., Scheltinga, D.M., 1996. The ultrastructure of spermatozoa of Squamata. II. Agamidae, Varanidae, Colubridae, Elapidae, and Boidae (Reptilia). Herpetologica $52,216-241$.

Poe, S., Wiens, J.J., 2000. Character selection and the methodology of morphological phylogenetics. In: Wiens, J.J. (Ed.), Phylogenetic Analysis of Morphological Data. Smithsonian Institution Press, Washington, DC, pp. 20-36.

Presch Jr., W.F., 1974. Evolutionary relationships and biogeography of the macroteiid lizards (Family Teiidae, Subfamily Teiinae). B. Southern California Acad. Sci. 73, 23-32.

Presch Jr., W.F., 1983. The lizard family Teiidae: is it a monophyletic group? Zool J. Linn. Soc. (London) 77, 189-197.

Reeder, T.W., Cole, C.J., Dessauer, H.C., 2002. Phylogenetic relationships of whiptail lizards of the genus Cnemidophorus (Squamata: Teiidae): a test of monophyly, reevaluation of karyotypic evolution, and review of hybrid origins. Am. Mus. Novit. 3365, 1-61.

Rieppel, O., 1980. The trigeminal jaw adductor musculature of Tupinambis, with comments on the phylogenetic relationships of the Teiidae (Reptilia Lacertilia). Zool. J. Linn. Soc. (Lond.) 69, $1-29$.

Ruibal, R., 1952. Revisionary studies of some South American Teiidae. B. Mus. Comp. Zool. 106, 477-529.

Tavares-Bastos, L., Teixeira, R.D., Colli, G.R., Bao, S.N., 2002. Polymorphism in the sperm ultrastructure among four species of lizards in the genus Tupinambis (Squamata: Teiidae). Acta Zool. (Stockholm) 83, 297-307.

Teixeira, R.D., Colli, G.R., Bao, S.N., 1999a. The ultrastructure of the spermatozoa of the wormlizard Amphisbaena alba (Squamata, Amphisbaenidae), and the phylogenetic relationships of amphisbaenians. Can. J. Zool. 77, 1254-1264.

Teixeira, R.D., Colli, G.R., Bao, S.N., 1999b. The ultrastructure of the spermatozoa of the lizard Micrablepharus maximiliani (Squamata, Gymnophthalmidae), with considerations on the use of sperm ultrastructure characters in phylogenetic reconstruction. Acta Zool. (Stockholm) 80, 47-59.

Teixeira, R.D., Scheltinga, D.M., Trauth, S.E., Colli, G.R., Bao, S.N., 2002. A comparative ultrastructural study of spermatozoa of the teiid lizards, Cnemidophorus gularis gularis, C. ocellifer, and K. altamazonica (Reptilia, Squamata Teiidae). Tissue \& Cell 34, 135-142.

Thiele, K., 1993. The holy grail of the perfect character: the cladistic treatment of morphometric data. Cladistics 9, 275-304.

Vanzolini, P.E., 1977. An Annotated Bibliography of the Land and FreshWater Reptiles of South America (1758-1975). Vol. I (1758-1900). Museu de Zoologia, Universidade de São Paulo, São Paulo, 186 pp.

Vanzolini, P.E., Valencia, J., 1965. The genus Dracaena, with a brief consideration of macroteiid relationships (Sauria Teiidae). Arq. Zool. (São Paulo) 13, 7-46. 
Veronese, L.B., Krause, L., 1997. Esqueleto pre-sacral e sacral dos lagartos teiıdeos (Squamata Teiidae). Revta. Bras. Zool. 14, 15-34.

Wiens, J.J., 1995. Polymorphic characters in phylogenetic systematics. Syst. Biol. 44, 482-500.

Wiens, J.J., 1998. Testing phylogenetic methods with tree congruence: Phylogenetic analysis of polymorphic morphological characters in phrynosomatid lizards. Syst. Biol. 47, 427-444.

Wiens, J.J., 2000. Coding morphological variation for phylogenetic analysis: polymorphism and interspecific variation in higher taxa. In: Wiens, J.J. (Ed.), Phylogenetic Analysis of Morphological Data. Smithsonian Institution Press, Washington, DC, pp. 115-145.

Zar, J.H., 1998. Biostatistical Analysis. Prentice-Hall, Inc, Englewood Cliffs, New Jersey, 663 pp. 